\title{
„Demokratizačná akcia“
}

\section{Študentské čistky na slovenských vysokých školách na prelome rokov 1948 a 1949}

\author{
Marta Glossová
}

Sú dva spôsoby, ako držat ludí: cez ich osobný život a cez ich deti. Ak protestujete, stratíte svoju pozíciu a vaše deti už nemajú žiadnu budúcnost. Sú skúšky. Je to vel'mi jednoduché - povedat, že vaše dieta neuspelo...

Bernard Noël: Stretnutie s Tatarkom ${ }^{1}$

Kontrola prístupu k vysokoškolskému, no aj k stredoškolskému vzdelaniu je jedným z nástrojov, ktoré totalitné režimy využívajú na zabezpečenie lojálnosti vlastných občanov a na potrestanie tých nelojálnych. V socialistickom Československu tieto praktiky v podobe politicky motivovaného neprijatia uchádzačov na štúdium dosiahli kvantitatívny vrchol v období takzvanej normalizácie. V mechanizme fungovania tunajšieho komunistického režimu však boli prítomné dávno predtým: v jeho „budovatel'skom“ období v pätdesiatych rokoch sa svojím rozsahom, brutálnostou a nezákonnostou zaradili k d’alším formám perzekúcií, ktorými sa predstavitelia

1 NOËL, Bernard: Stretnutie s Tatarkom. In: Revue Impulz, roč. 13, č. 1 (2017), s. 86-104, tu s. 98. Z francúzštiny preložila Katarína Chaloupková. Text francúzskeho novinára pochádza z roku 1980. Dostupné aj zo: http://www.impulzrevue.sk/article.php?1422. 
etablujúcej sa totality snažili zlomit odpor potenciálnych protivníkov a premenit sociálnu a politickú štruktúru spoločnosti a jej jednotlivých skupín.

Študenti a študentky vysokých škôl predstavovali skupinu, ktorej lojálnost̉ a - dobovým výrazom - „politickú uvedomelost" - činitelia režimu strážili obzvlášt bedlivo. Vybudovanie lojálnych elít je totiž dôležitým ciel’om každého režimu, obzvlášt totalitného, ktorého stabilita je okrem strachu postavená predovšetkým na pevnej hierarchii ludí spolahlivo slúžiacich ideológii štátu. Okrem ideovo-politickej výchovy k tomuto cielu malo po februári 1948 viesṫ niekol'ko systematicky uplatňovaných prostriedkov, ako bolo ovplyvňovanie výberu študujúcich na základe prijímacích pohovorov, posilňovanie počtu „triedne vyhovujúcich“vysokoškolákov prostredníctvom prijímania absolventov prípravných robotníckych kurzov a robotníkov študujúcich popri zamestnaní - a súčasne tiež vylučovanie „nevyhovujúcich“ študentov a študentiek, ktoré sa pod rôznymi zámienkami na vysokých školách odohrávalo.

„Previerky a vylučovanie študentov slovenských vysokých škôl v rokoch 1948-1960 ako nástroj výchovy lojálnych elít" sú témou dizertačnej práce, ktorú som obhájila na Filozofickej fakulte Univerzity Komenského v Bratislave v júni 2019. Hoci v českom prostredí ide o bohato spracovanú tému, ${ }^{2}$ na Slovensku sa jej doteraz nikto systematicky nevenoval. ${ }^{3} \mathrm{~V}$ dôsledku doposial chýbajúceho primárneho výskumu v slovenských archívoch sa zistenia z českých vysokých škôl v mnohých prípadoch v odbornej literatúre automaticky vztahujú na celé Československo, teda aj na slovenské vysoké školy. Tohto zjednodušenia sa dopúštajú nielen českí autori, ale aj americký historik John Connelly, ktorého publikácia Zotročená univerzita, venovaná sovietizácii vysokého školstva v krajinách strednej Európy, sa stala bestsellerom a „bibliou“ tejto problematiky. ${ }^{4}$

Ako však ukázal môj výskum v Slovenskom národnom archíve a v archívoch jednotlivých slovenských vysokých škôl, napriek spoločným rámcovým krokom existovali medzi študentskými čistkami na slovenských a českých vysokých školách pomerne velké rozdiely. Tie niekedy spočívali v časových posunoch a formálnych odlišnostiach mechanizmov preverovania a vylučovania študentov a študentiek zo

2 Pojednávajú o nej práce Jakuba Jareša, Jaroslava Cuhru, Marie Černej, Pavla Urbáška, Jiřího Pulca, Vladimíry Hradeckej a mnohých d’alších autorov a autoriek.

3 Paradoxne najprínosnejšou prácou $\mathrm{k}$ tejto téme je pamätnica Pätdesiat rokov Univerzity Komenského z roku 1969, ktorá sa pomerne otvorene venuje pomerom na bratislavskej univerzite v 50. rokoch minulého storočia a aj samotným čistkám (VARSÍK, Branislav (ed.): Pätdesiat rokov Univerzity Komenského: Vydané z príležitosti 50. výročia založenia Univerzity Komenského v Bratislave. Bratislava, Univerzita Komenského 1969). Okrem tejto publikácie sa témou študentských previerok a čistiek na Slovensku podrobnejšie zaoberajú už len dve práce: doposial nepublikovaná rigorózna práca študentky Pedagogickej fakulty Univerzity Komenského Ludmily Durajovej Perzekúcie slovenských vysokoškolských študentov v rokoch 1945-56 z roku 2005 a nová publikácia Sone Gabzdilovej, ktorá však má do vel'kej miery prehladový charakter (GABZDILOVÁ, Soňa: Ako sme študovali v totalite: Vysokoškolské vzdelávanie na Slovensku pod ideologickým diktátom Komunistickej strany Československa (1948-1953). Prešov, UNIVERSUM-EU 2018).

4 CONNELLY, John: Zotročená univerzita: Sovětizace vysokého školství ve východním Německu, $v$ českých zemích a v Polsku v letech 1945-1956. Praha, Karolinum 2000. 
slovenských vysokých škôl, ktoré vyplývali z asymetrie štátnej správy, spôsobenej existenciou a kompetenciami slovenského povereníctva školstva, ktoré okrem centrálnych vládnych pokynov vydávalo aj vlastné, niekedy mierne odlišné smernice.

Ovela zaujímavejšie sú však odlišnosti, ktoré boli zapríčinené rozdielnou personálnou situáciou a sociokultúrnymi parametrami v oboch častiach krajiny. Jedným z markantných rozdielov bola kontinuita vysokoškolského vzdelávania na Slovensku počas druhej svetovej vojny na rozdiel od jeho disrupcie na českých vysokých školách, ktorá okrem iného spôsobila pretlak českých študentov a študentiek a ich relatívne vyšší priemerný vek v prvých rokoch po oslobodení, čo prispelo k ich aktívnejšej politickej angažovanosti a po februári 1948 aj k strmšiemu úbytku počtu vysokoškolákov v dôsledku čistiek. Obyvatelia Slovenska si tiež niesli nedávnu skúsenosṫ z obdobia Slovenského štátu (1939-1945), počas ktorého sa ujali viaceré fenomény reštrikcie, prítomné a známejšie skôr v období od roku 1948, ako napríklad diskriminačný prístup $\mathrm{k}$ vzdelaniu či prax politických previerok na vysokých školách. Tie boli na Slovensku súčastou relatívne „normálneho života“ v štáte spravovanom vlastnou elitou, na rozdiel od situácie v nepriatelom okupovanej krajine. Tieto pomery vytvárali mnohé príležitosti pre morálne kompromisy a zanechali svoje dôsledky aj po komunistickom prevrate, ktorý síce zaviedol novú ideológiu, ale jej mechanizmy zostali v mnohom rovnaké. Pre Slovensko tiež bola typická ovela mladšia, zomknutejšia a užšia intelektuálna elita a celkový nedostatok vysokoškolsky vzdelaných odborníkov nielen na vysokých školách, ale aj v štátnej správe a v hospodárskej sfére, ktorý z praktických dôvodov neumožňoval také prudké a masové čistky ako v českých krajinách.

Dôsledkom týchto rozdielov bol jednak relatívne nižší počet študujúcich vylúčených zo slovenských vysokých škôl a jednak čiastočne odlišný priebeh ich vylučovania. Odlišnost spočívala predovšetkým v tom, že kým na českých vysokých školách sa odohrala čistka medzi študentstvom (a rovnako učitelmi) relatívne naraz, pričom rozhodujúcu rolu v prípade študentov a študentiek zohrala takzvaná studijní prověrka, na Slovensku mala táto akcia pod označením „demokratizácia“ zdanlivo miernejší priebeh, navyše mnoho vylúčených študujúcich uspelo v odvolacom konaní. ${ }^{5}$ Personálna prestavba slovenských vysokých škôl však pokračovala a dospela k svojmu vrcholu v roku 1950, ked’ vysoké školy, rovnako ako celú slovenskú spoločnost', zasiahla ideologická kampaň proti takzvanému buržoáznemu nacionalizmu; ${ }^{6}$ jej obetou sa medzi prvými stal aj povereník školstva, básnik Laco Novomeský. Študentská čistka motivovaná týmto ideologickým bojom na slovenských vysokých školách prebehla v dvoch vlnách - v júni a na jeseň 1950 - a bolo

5 Na českých vysokých školách nebolo počas tejto „študijnej previerky“v roku 1949 preverených 10203 študentov a študentiek, čo je 25,7 percent (pozri URBÁŠEK, Pavel - PULEC, Jiř́: Vysokoškolský vzdělávací systém v letech 1945-1969. Olomouc, Univerzita Palackého 2002, s. 100). Na Slovensku bolo pri „demokratizácii“ vylúčených 1038 študujúcich, čo predstavovalo „len“ 10,4 percenta.

6 Rovnako ako samotný „slovenský buržoázny nacionalizmus“ bola aj táto čistka slovenským špecifikom - zatial' sa nepreukázalo, že by v tejto súvislosti došlo k d’alšej čistke aj na českých vysokých školách. 
počas nej vylúčených d’alších 570 študentov a študentiek. ${ }^{7}$ Až počas tejto druhej čistky sa tak na slovenských školách definitívne zavŕšila ich personálna prestavba, a to nielen $\mathrm{v}$ prípade študentstva, ale aj pedagogického zboru. ${ }^{8}$

Popri „demokratizácii“ a dvoch etapách čistky v rámci „ideologického boja“ v roku 1950 sa preverovanie a vylučovanie vysokoškolákov na Slovensku v rokoch 1948 až 1960 odohrávalo v d’alších piatich vlnách. Niektoré z nich mali svoje české paralely, $v$ iných prípadoch išlo o špecificky slovenské javy. Chronologicky možno všetky tieto perzekučné akcie zhrnút do nasledujúceho prehladu:

1. Vylučovanie zo štúdia z rozhodnutia akčných výborov na vysokých školách po februári 1948;

2. „demokratizačná akcia“ na jar 1949;

3. blesková čistka v rámci kampane proti „slovenskému buržoáznemu nacionalizmu“"v júni 1950;

4. čistka v rámci „boja za ideologickú čistotu vysokých škôl“" v septembri a októbri 1950;

5. vylučovanie zo štúdia na stredných a vysokých školách $\mathrm{v}$ súvislosti s takzvanou Akciou B - „Očistou velkých miest“ v rokoch 1952 a 1953, ktoré bolo automatickým dôsledkom vystahovania vytipovaných „nepriatel'ských“ rodín z týchto miest;

6. priebežné politicky motivované vylučovanie jednotlivcov disciplinárnymi komisiami a kádrovými oddeleniami vysokých škôl v rokoch 1950 až 1956; ${ }^{9}$

7. vylučovanie zo štúdia a d’alšie perzekúcie $\mathrm{v}$ reakcii na študentské protesty v roku 1956;

8. vylučovanie jednotlivcov v dôsledku konsolidácie a sprísnenia politického režimu v rokoch 1956 až 1960. ${ }^{10}$

„Demokratizačná akcia“ na Slovensku z prelomu rokov 1948 a 1949, ktorá je témou tejto štúdie, tvorila do vel'kej miery paralelu k vtedajšej „študijnej previerke“

7 To pri aktuálnom (po „demokratizácii“ zredukovanom) počte študujúcich a pri odpočítaní nastupujúcich prvákov, ktorí boli preverovaní v osobitnom režime, predstavovalo d’alších 11,12 percent vylúčených.

8 Pozri HUDEK, Adam: Najpolitickejšia veda: Slovenská historiografia v rokoch 1948-1968. Bratislava, Historický ústav SAV 2010, s. 105.

9 Išlo o rôzne prípady, ked' boli študujúci vylučovaní v dôsledku politicky motivovaného trestného stíhania ich samých alebo ich rodinných príslušníkov, v dôsledku ich (náhodne alebo po udaní zistených) „kádrových nedostatkov“, eventuálne v dôsledku „politickej nespolahlivosti“ študujúcich alebo ich príbuzných (napr. emigrácie, politickej činnosti počas Slovenského štátu, „buržoázneho povolania“ rodičov, lepšej majetkovej situácie rodiny, obvinenia z „idealizmu“ - t.j. náboženskej viery - a pod.).

10 Formou aj mechanizmom išlo o podobné prípady ako pred rokom 1956 (pozri pozn. 9), pričom sa však kládol zvýšený dôraz na správny „triedny pôvod“ študentov a študentiek. Týkalo sa to najmä oneskorene zistených „kádrových závad“ vo vztahu k období Slovenského štátu, ako bolo (skutočné alebo vymyslené) členstvo rodičov v Hlinkovej slovenskej ludovej strane, Hlinkových gardách či v Nemeckej strane (Deutsche Partei), určitá živnost či administratívna pozícia otca (notár, vládny komisár), účast̉ rodičov (skutočná alebo vymyslená) pri arizácii, nemecký pôvod a pod. 
v českých krajinách a rozdiely medzi týmito udalostami spočívajú skôr v detailoch. Neusilujem sa tu ich komparáciou poukazovat na odlišnosti medzi oboma častami Československej republiky pri ideologicky motivovanom očistovaní vysokých škôl po februári 1948, ale skôr doplnit a načrtnút celkový obraz „demokratizačnej akcie“ na základe výsledkov môjho archívneho výskumu na Slovensku. S prihliadnutím k tomu bude možné upriamit pozornost na hlbšie rozdiely pri d’alších fázach ideologizácie slovenských vysokých škôl oproti situácii v českých krajinách, čo už ale presahuje rozsah tejto štúdie.

Na rozdiel od stavu prameňov v Archíve Univerzity Karlovej, v ktorom sa podarilo zachovat pracovné materiály z činnosti previerkových komisií, ${ }^{11}$ sú bádatelia na Slovensku odkázaní len na oficiálne dokumenty povereníctva školstva a vnútra, straníckych orgánov či vysokých škôl. Materiály samotných previerkových komisií, rovnako ako fakultných straníckych organizácií, ktoré v študentských čistkách zohrali klúčovú rolu, sa v univerzitných a oblastných archívoch na Slovensku ani v Slovenskom národnom archíve nezachovali (respektíve sa nepodarilo zistit', kde boli uložené).

Východiskovým archívnym materiálom pre môj výskum tak boli predovšetkým smernice, korešpondencia, hodnotiace správy a štatistické prehlady o jednotlivých previerkach na vysokých školách, ktoré možno nájsť v Slovenskom národnom archíve (vo fondoch sekretariátu a tajomníkov Ústredného výboru Komunistickej strany Slovenska a vo fonde Povereníctva školstva Slovenskej národnej rady). Fond štvrtého (školského) oddelenia ÚV KSS, ktorý je tiež v správe Slovenského národného archívu, je zatial' nespracovaný a neprístupný. Túto oficiálnu dokumentáciu čiastočne doplńajú vyjadrenia vylúčených študentov, ktoré boli súčastou ich odvolaní bezprostredne po vylúčení alebo žiadostí o rehabilitáciu v roku 1969 a ktoré sa zachovali v archívoch jednotlivých vysokých škôl. ${ }^{12}$ Okrem archívneho výskumu sa vo svojej práci opieram o odbornú, ale aj dobovú literatúru a študentskú tlač (najmä študentský časopis Borba).

11 Viz JAREŠ, Jakub: „Indiferentní - možnost převýchovy!“Cíle tzv. studijní prověrky na vysokých školách a jejich realizace. In: ČERNÁ, Marie - CUHRA, Jaroslav (ed.): Prověrky a jejich místo v komunistickém vládnutí: Československo 1948-1989. Praha, Ústav pro soudobé dějiny AV ČR, v.v.i. 2012, s. 21.

12 Pri bádaní som využívala archívy Univerzity Komenského v Bratislave (dobovým názvom Slovenská univerzita v Bratislave), Slovenskej technickej univerzity v Bratislave (Slovenskej vysokej školy technickej) a Ekonomickej univerzity v Bratislave (Vysokej školy hospodárskych vied). Ostatné slovenské vysoké školy vznikli až v neskoršom období, preto sa im v štúdii nevenujem. Aj sprístupňovanie týchto materiálov však bolo vzhladom na aktuálne znenie zákona o ochrane osobných údajov vel'mi komplikované. 


\section{Vysoké školstvo na Slovensku po druhej svetovej vojne}

Moderné vysoké školstvo na Slovensku nemalo dlhú tradíciu. ${ }^{13}$ Prvá moderná vysoká škola v Bratislave bola zriadená spolu s univerzitou v Brne po vzniku Československa v roku 1919. Jej pôvodný aj súčasný názov Univerzita Komenského bol v rokoch 1939 až 1954 nahradený názvom Slovenská univerzita. V období, na ktoré zameriava pozornoste táto štúdia, mala Slovenská univerzita právnickú, lekársku, filozofickú, prírodovedeckú, farmaceutickú a pedagogickú fakultu a bola najväčšou a najdôležitejšou slovenskou univerzitnou inštitúciou. Okrem nej na Slovensku pôsobili ešte tri mladučké vysoké školy - Slovenská vysoká škola technická (od roku 1937), ${ }^{14}$ Slovenská vysoká škola obchodná, respektíve Vysoká škola hospodárskych vied (od roku 1940) ${ }^{15}$ a Vysoká škola pol'nohospodárskeho a lesníckeho inžinierstva v Košiciach (od roku 1946). ${ }^{16}$

Počet študujúcich na slovenských vysokých školách sa v tridsiatych rokoch minulého storočia pohyboval tesne nad hranicou dvoch tisíc. ${ }^{17} \mathrm{~K}$ výraznejšiemu nárastu ich počtu došlo až v školskom roku 1937/1938 a najmä 1940/1941, k čomu okrem atmosféry priaznivejšej pre rozvoj vlastných „slovenských“ akademických inštitúcií (v roku 1942 vznikla tiež Slovenská akadémia vied a umení) prispelo predovšetkým založenie nových vysokých škôl (technickej v roku 1937 a ekonomickej v roku 1940). Rozbitie Československa a zatvorenie českých vysokých škôl v roku 1939 tiež spôsobilo, že určitý počet slovenských poslucháčov, ktorí tradične študovali na českých vysokých školách, bol nútený zostat na Slovensku.

13 V stredoveku a novoveku na území dnešného Slovenska pôsobilo niekol'ko univerzitných inštitúcií, ktoré si však z rôznych dôvodov nezachovali kontinuitu do dvadsiateho storočia. Za najstaršiu vysokoškolskú inštitúciu sa považuje Academia Istropolitana v Bratislave (1467-1490). Okrem nej formovali univerzitnú tradíciu na Slovensku aj Trnavská univerzita (1635-1777), Banská akadémia v Banskej Štiavnici (1770-1919), právnické akadémie v Košiciach a Trnave a Alžbetínska univerzita v Bratislave (1912-1919).

14 SVŠT vznikla v Košiciach, od roku 1939 pôsobila v Bratislave.

15 V rokoch 1940-1945 súkromná Vysoká obchodná škola v Bratislave, po zoštátnení v roku 1945 Slovenská vysoká škola obchodná, od roku 1949 Vysoká škola hospodárskych vied, od roku 1952 Vysoká škola ekonomická a od roku 1992 do súčasnosti Ekonomická univerzita v Bratislave.

16 Škola bola predchodkyňou dnešnej Slovenskej pol’nohospodárskej univerzity a Technickej univerzity vo Zvolene.

17 Pozri graf č. 1, ktorý zobrazuje vývoj počtu študentov a študentiek na Slovensku v rokoch 1931-1948 na základe viacerých štatistických príručiek. 
Graf 1: Počet poslucháčov slovenských vysokých škôl v rokoch 1931-1948

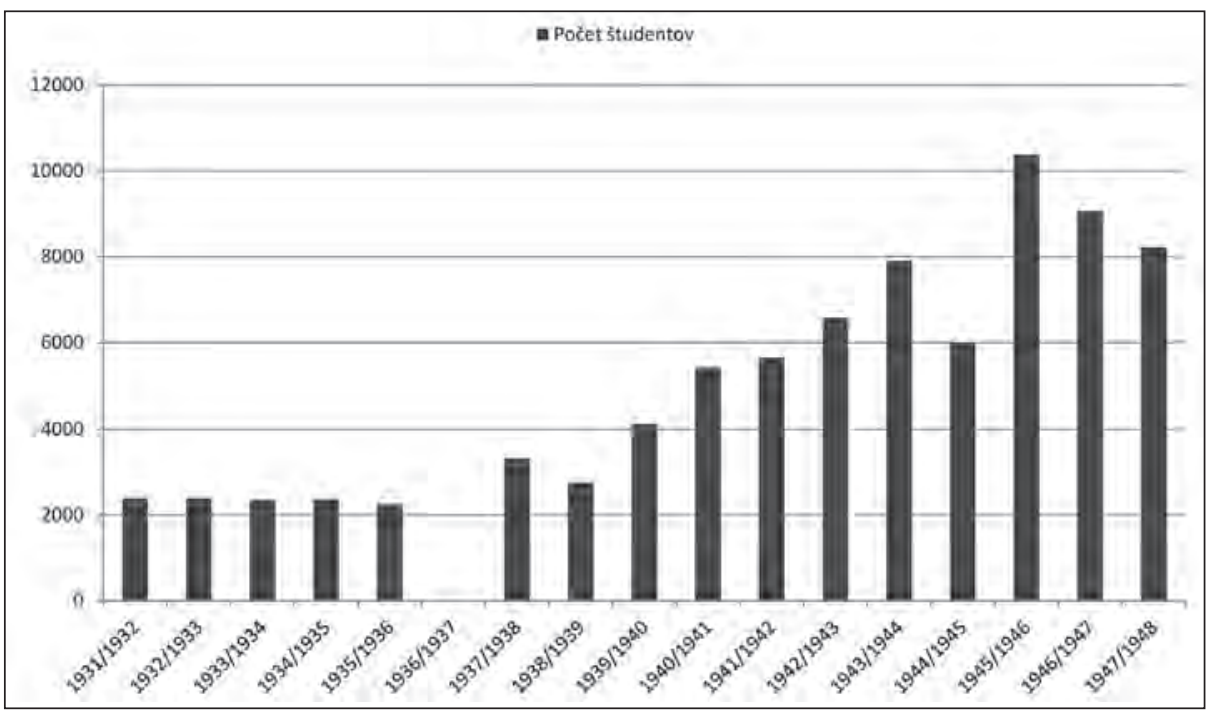

Skokový nárast priniesol školský rok 1945/1946, kedy počet vysokoškolákov na Slovensku po prvykrát prekročil desat tisíc. Tento velký, takmer dvojnásobný vzostup (z 5989 v školskom roku 1944/1945 na 10376 v roku 1945/1946) súvisel jednak s obnovením normálneho fungovania všetkých oblastí spoločenského života vrátane školstva po oslobodení, no prejavilo sa v ňom aj kompenzovanie poklesu z roku 1944/1945 (takmer o dva tisíce študujúcich medziročne). ${ }^{18} \mathrm{~V}$ náraste počtu vysokoškolákov v školskom roku 1945/1946 sa mohol premietnut aj pretlak uchádzačov o štúdium na obnovených českých vysokých školách; o tomto pohybe však neexistujú spolahlivé štatistické materiály. Výnimočnosť tohto ročníka však potvrdzuje následné zníženie počtu študujúcich pod hranicu desiatich tisíc, ktoré pretrvávalo až do školského roku 1952/1953. ${ }^{19}$

18 Tento pokles bol dôsledkom provizórneho fungovania štátu po vypuknutí Slovenského národného povstania, ked’ bola vyhlásená mobilizácia, niektorí vysokoškoláci sa zapojili do povstania, bola narušená dopravná infraštruktúra atd'.

19 Pozri grafy č. 2 a 3, ktoré zobrazujú vývoj počtu študentov a študentiek na Slovensku v rokoch 1945-1960 v porovnaní s vývojom v Čechách a na Morave v rovnakom období. Údaje sú čerpané z Historickej statistickej ročenky ČSSR (Praha, Federální statistický úruad 1985, s. 595 (pre Českú republiku) a s. 794 (pre Slovenskú republiku). 
Graf 2: Počet poslucháčov vysokých škôl na Slovensku v rokoch 1945-1960

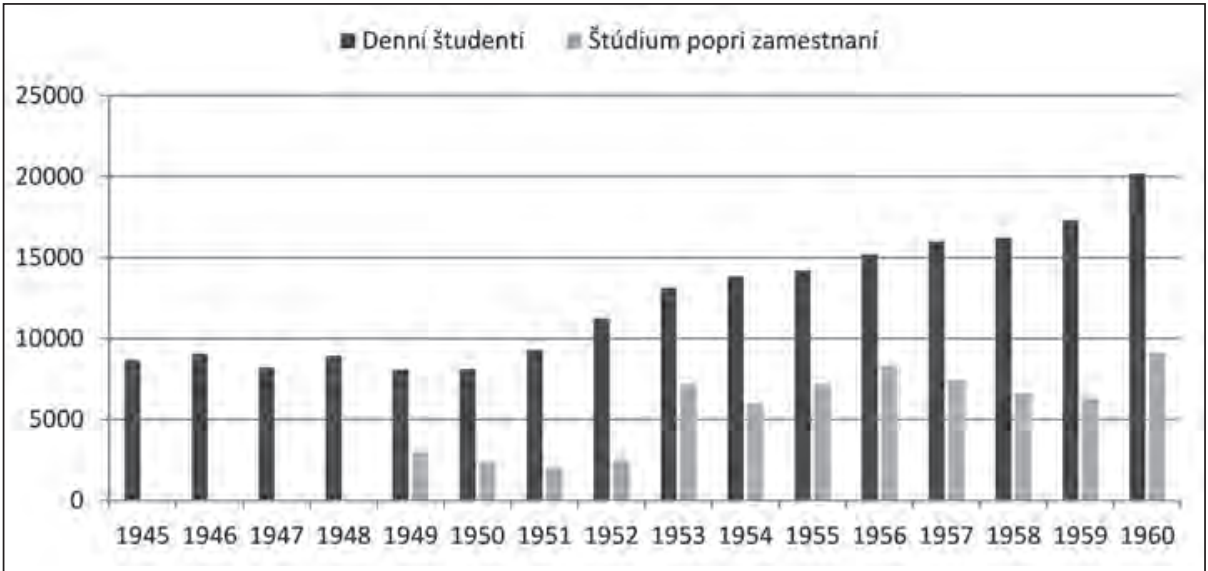

Graf 3: Počet poslucháčov vysokých škôl v Čechách a na Morave v rokoch 1945-1960

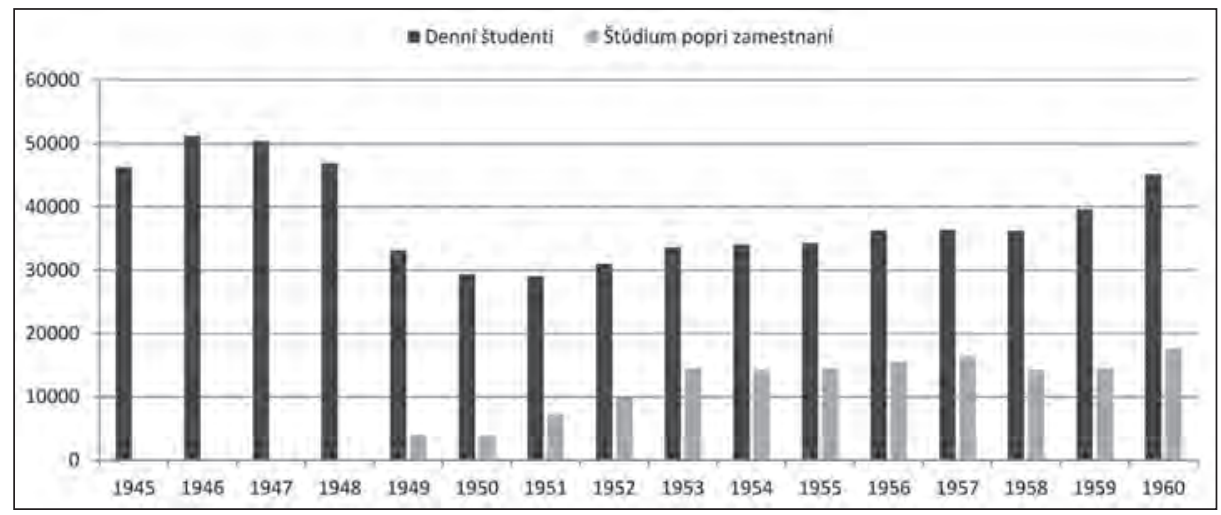

Za pomerne markantným poklesom počtu študujúcich na slovenských vysokých školách v roku 1949 a jeho stagnáciou v roku 1950 treba vidiet masové čistky v týchto rokoch v podobe „demokratizačnej akcie“. Celkový počet poslucháčov síce zároveň dopíňali uchádzači prijatí na mimoriadne formy štúdia (štúdium popri zamestnaní), no z pohladu absolútnych čísel aj napriek tomu došlo medzi školskými rokmi 1949/1950 a 1950/1951 k poklesu o približne sedemsto študentov a študentiek (z 11327 na 10 602). Ani novoprijatí „robotnícki“ študujúci tak nestačili na doplnenie tohto úbytku, spôsobeného vylúčením stoviek poslucháčov, nieto na rast ich počtu. Počet vysokoškolákov sa opät zretel’ne zvýšil až v roku 1951, ked' sa skončilo obdobie najmasívnejších čistiek a zároveň sa začali prejavovat „demokratizačné“ a „masifikačné“ opatrenia vyplývajúce z nového vysokoškolského zákona, prijatého v roku 1950. 


\section{Seba-sovietizácia školstva}

Vysoké školstvo v Československu - a v širšom zmysle aj školstvo ako také - prešlo $\mathrm{v}$ druhej polovici štyridsiatych a $\mathrm{v}$ pätdesiatych rokoch zásadnou premenou. Tá z medzivojnového a vojnového školstva, ktoré v mnohom fungovalo ešte podla predpisov a modelov z obdobia Rakúsko-Uhorska, ${ }^{20}$ vytvorila jednotný školský systém, ktorého základné princípy tvoria štruktúru školského systému v Česku a na Slovensku dodnes. Táto reforma predovšetkým pretvárala československé školstvo podla sovietskeho vzoru, no v čase svojho vzniku reagovala aj na špecifické požiadavky povojnovej spoločnosti, ktoré boli do značnej miery spoločné pre celú Európu. Išlo napríklad o zvyšovanie efektivity riadenia vysokých škôl, „masifikáciu“ a expanziu vzdelávania, demokratizáciu, regionalizáciu, internacionalizáciu alebo technizáciu vysokého školstva, ktoré sa v tomto období presadzovali aj na západných vysokých školách. ${ }^{21}$ Nový vysokoškolský zákon, ktorý petrifikoval niektoré už uskutočnené zmeny a zároveň definoval nové fungovanie vysokého školstva, bol v Československu prijatý až v máji 1950. ${ }^{22}$ Dva prelomové akademické roky 1948/1949 a 1949/1950 sú však zároveň charakteristické živelným fungovaním akademického života, ked' reforma ešte síce nemala legislatívnu podobu, no mnohé zmeny, predovšetkým pokial' sa týkali štátnej a straníckej kontroly nad vysokými školami, sa už diali prostredníctvom právne neukotvených prvkov v podobe prítomnosti komunistických organizácií na fakultách, činnosti akčných výborov a ich zasahovania do bežného života vysokých škôl, tlaku na ideologizáciu obsahu vzdelávania a podobne.

Tieto reformy, ktoré vysoké školstvo v Československu a ostatných krajinách východného bloku pripodobňovali sovietskemu modelu, americký historik John Connelly označuje termínom „sovietizácia“, ${ }^{23}$ teda „čo najdokonalejšie napodobnenie vysokoškolského systému fungujúceho v Sovietskom zväze““. ${ }^{24} \mathrm{~K}$ sovietizácii v pravom zmysle slova (v podobe vysokoškolskej politiky cielene importovanej prostredníctvom sovietskych zástupcov) však spomedzi týchto krajín došlo len vo východnom Nemecku, kde pre tento účel vzniklo špeciálne Školské oddelenie Sovietskej vojenskej správy v Karlshorste. ${ }^{25}$ V Pol'sku a Československu z viacerých dôvodov takýto priamy prenos nefungoval a proces pripodobňovania sa sovietskemu vzoru možno nazvat skôr seba-sovietizáciou, ${ }^{26}$ teda aktívnou snahou miestnych

20 Najstaršie nariadenia, ktoré zrušil nový vysokoškolský zákon, boli ešte z roku 1850.

21 Pozri napr. JAREŠ, Jakub: Dějiny vysokého školství v Československu po roce 1945: Otázky a podněty. In: Acta Universitatis Carolinae, roč. 52, č. 1 (2013), s. 13-24.

22 Zákon o vysokých školách, č. 58 z 18. mája 1950. In: Slov-Lex: Právny a informačný portál [online]. Bratislava, Ministerstvo spravodlivosti SR [cit. 2019-07-14]. Dostupné z: https:// www.slov-lex.sk/pravne-predpisy/SK/ZZ/1950/58/vyhlasene_znenie.html.

23 CONNELLY, J.: Zotročená univerzita, s. 76 (pozri pozn. 4).

24 HUDEK, Adam: Sovietizácia pracovísk historickej vedy na Univerzite Komenského v 50. rokoch. In: SLOBODNÍK, Martin - GLOSSOVÁ, Marta (ed.): 95 rokov Filozofickej fakulty UK a pohlad do dejín inštitúcie a jej akademickej obcie: Zborník z konferencie. Bratislava, Univerzita Komenského v Bratislave 2017, s. 338-354, tu s. 339.

25 Pozri CONNELLY, J.: Zotročená univerzita, s. 77.

26 Tamže, s. 85. 
komunistických špičiek o otrocké kopírovanie sovietskeho školstva. To však, ako pripomína Connelly, často prebiehalo až bizarným spôsobom, horlivo, ale diletantsky, bez dostatočného množstva informácíi a literatúry, ked” autori „seba-sovietizačných“" reforiem boli do velkej miery namiesto poznania aktuálnych trendov sovietskeho vysokého školstva odkázaní len na vlastnú skúsenost̉ z pobytu v Sovietskom zväze, často pomerne dávnu. Charakteristickými prvkami týchto premien vysokého školstva vo východnom bloku boli rozbitie autonómie a samosprávy vysokých škôl, ich podriadenie štátnemu a straníckemu riadeniu prostredníctvom zásadných štrukturálnych a kompetenčných zmien a personálnych zásahov a napokon direktívne presadzovaná ideologizácia obsahu vzdelávania. Dôležitými piliermi sovietskeho typu vysokého školstva ${ }^{27}$ boli jeho „straníckost“, teda „úplné stotožnenie sa s aktuálnou straníckou politikou a jej aktívna podpora" ${ }^{28}$ a okamžitá uplatnitel'nost absolventov štúdia v hospodárstve štátu. K tomuto cielu malo smerovat aj rozsiahle plánovanie a určovanie smerných čísel na prijímanie uchádzačov o štúdium, respektíve ich redistribúcia na odbory, ktoré štát podla plánov aktuálne potreboval posilnit. Ako však pripomína slovenský historik Adam Hudek, medzi týmito dvomi princípmi v praxi často dochádzalo k rozporu, ked' si bolo nutné vybrat medzi odborníkmi, no bez dokonalej politickej spol’ahlivosti, alebo sa uspokojit s presvedčenými straníkmi, no bez dostatočnej profesionálnej erudície. ${ }^{29} \mathrm{Na}$ Slovensku to bolo vzhl'adom na poddimenzovanost a nepočetnost vysokoškolsky vzdelanej inteligencie obzvlášt vel'kým problémom, ktorý zásadným spôsobom prispel k pomalšiemu nástupu sovietizácie na vysokých školách a k miernejšiemu a oneskorenému priebehu personálnych čistiek učitelov aj študentov.

\section{Termín „demokratizácia“}

Samotný pojem demokratizácia nebol v povojnovom politickom diskurze v Československu nový. Ked’že ho vztiahneme priamo k oblasti školstva, explicitnú požiadavku sprístupnit vzdelanie všetkým občanom, a nie len úzkej privilegovanej skupine, obsahoval už Košický vládny program: „Bude provedena di̊sledná demokratizace, a to nejen umožnění co nejširším vrstvám přístupu do škol i k jiným pramenům vzdělání a kultury, ale i v ideovém směru: v zlidovění samého systému výchovy i povahy kultury, aby sloužila ne úzké vrstvě lidí, ale lidu a národu.“" ${ }^{30}$ Demokratizácia

27 K systému sovietskeho vysokého školstva pozri DAVID-FOX, Michael - PÉTERI, György: On the Origins and Demise of the Communist Academic Regime. In: TÍ ISTÍ (ed.): Academia in Upheaval: Origins, Transfers, and Transformations of the Communist Academic Regime in Russia and East Central Europe. London - Westport, Bergin \& Garvey 2000, s. 3-38.

28 HUDEK, A.: Sovietizácia pracovísk historickej vedy na Univerzite Komenského v 50. rokoch, s. 340 , pozn. 3 .

29 Tamže, s. 340.

30 Košický vládní program 5. 4. 1945. In: Moderní dějiny: Vzdělávací portál pro učitele, studenty a žáky [online]. (C) Občanské sdružení PANT 2009-2019 [cit. 2019-07-18]. Dostupné z: http://www.moderni-dejiny.cz/clanek/kosicky-vladni-program-5-4-1945/. 


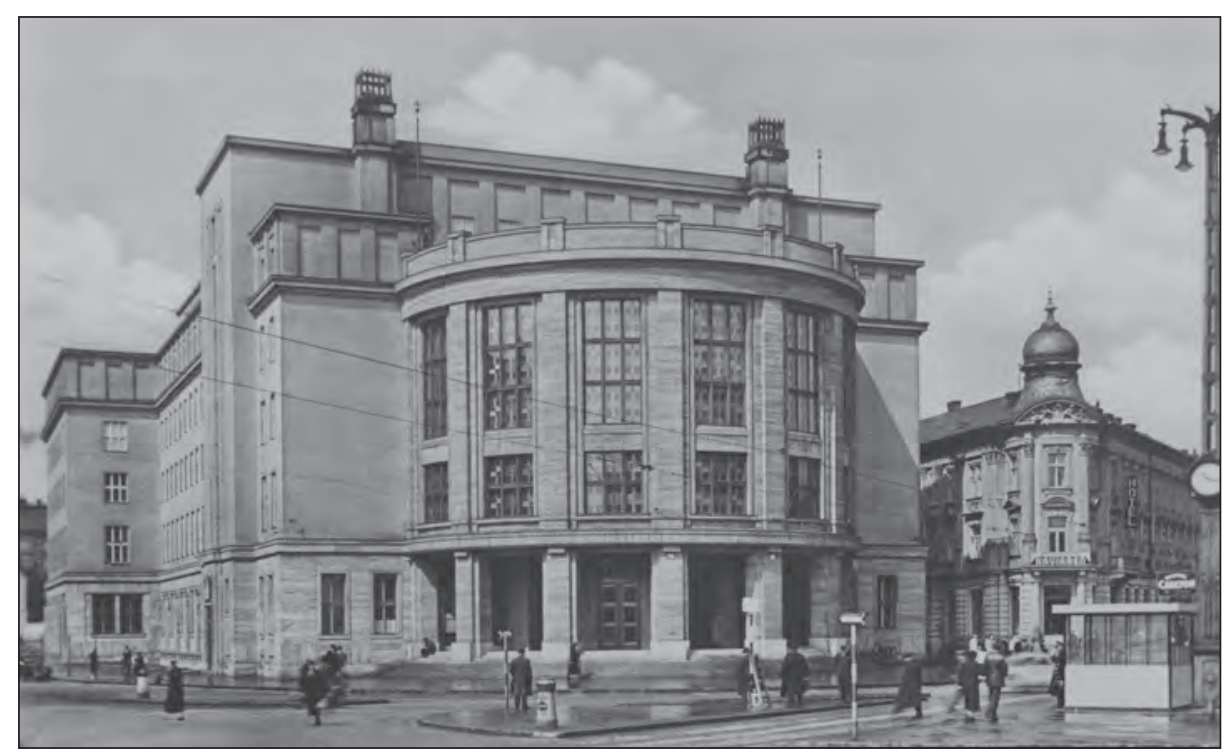

Budova Slovenskej univerzity (dnešnej Univerzity Komenského) v Bratislave niekedy $v$ rokoch 1948-1953 (foto Súkromná zbierka Juraja Horvátha, PamMap.sk)

tak mala ukončit domnelý monopol tejto (nedefinovanej) privilegovanej skupiny na vzdelanie a sprístupnit ho všetkým občanom bez ohladu na ich majetkové pomery či sociálny pôvod.

Takéto využívanie pojmu „demokratizácia“ úzko súvisí so zmenou v chápaní významu samotného termínu „demokracia“, ku ktorému v československom politickom a mediálnom diskurze došlo v prvých rokoch po oslobodení. Ústredným pojmom sa stala l'udová demokracia. V kontraste s medzivojnovou demokratickou kultúrou tento pleonazmus vystihoval zvláštne zdôrazňovanie „ludovosti“ vlády ludu (demo-kracie) ${ }^{31}$ ktoré sa prejavovalo rovnostárskym chápaním sociálnej spravodlivosti, deklarovaným sociálnym pokrokom aj posilnenou pozíciou štátu, realizovanou aj „znárodnením" velkých podnikov, centrálne plánovaným hospodárstvom a režimom obmedzenej parlamentnej demokracie. Luudová demokracia tak získala význam - prinajmenšom v očiach tých, ktorí verili v ideály socializmu - prechodného štádia medzi liberálnou demokraciou a socialistickým režimom. Predvojnové demokratické zriadenie bolo vykreslované ako nedostatočne demokratické s tým, že „možnosti participace občanů byly omezovány byrokraty, stranickými aparáty a politiky z povoláni““ a že „velké části obyvatelstva byly na základě svého ekonomického znevýhodnění kráceny i na svých politických právech“. ${ }^{32}$

31 BRENNER, Christiane: Mezi Východem a Západem: České politické diskurzy 1945-1948. Praha, Argo 2015, s. $82 \mathrm{n}$.

32 Tam̌̌e, s. 84 n. 
Z takého pohladu, ktorý sa stal po februári 1948 oficiálnym naratívom, vychádzala „demokratizačná“ rétorika pri zdôvodňovaní nasledujúcich študentských čistiek na vysokých školách. Obhajcovia argumentovali, že v predchádzajúcom období mala na univerzitné vzdelanie monopol mládež z „buržoáznych rodín“, čo bolo jednak nespravodlivé voči študentom z robotníckeho a rolníckeho prostredia, no zároveň sa negatívne prejavovalo v slabej študijnej morálke takzvanej zlatej mládeže, ktorá si štúdium nevážila. Sprístupnenie vysokoškolského štúdia všetkým - teda najmä robotníckym - uchádzačom a zároveň vylúčenie doposial” „nedemokraticky“ privilegovaných študentov sa tak stalo ústredným motívom oficiálneho zdôvodnenia „demokratizačnej akcie“ na Slovensku rovnako ako „študijnej previerky“ v Čechách a na Morave. Ako argument však slúžilo aj po celé nasledujúce desatročie, počas ktorého sa v kádrovej politike vysokých škôl s kolísajúcim dôrazom neustále objavoval faktor triedneho pôvodu študentov a študentiek, ktorý mal proporčne zodpovedat sociálnej stratifikácii spoločnosti. Úspech tejto politiky bol však len čiastočný: podiel študujúcich robotníckeho a rolníckeho pôvodu v rokoch 1948 až 1960 síce stúpol, no ani napriek vyslovene pozitívne diskriminačnej politike nikdy nepresiahol štyridsattri percent, ${ }^{33}$ kým dobové údaje o "triednej skladbe“ obyvatel'stva hovorili až o sedemdesiatich percentách občanov robotníckeho a rol'níckeho pôvodu. ${ }^{34}$ Ako výstižne poznamenal John Connelly, komunistická strana v Československu nedokázala „se stejnou vervou, s jakou si vyř́ílila účty se starou elitou, vytvořit elitu novou. I když se jí podařilo (čistkami - pozn. autorky) udělat ze studentů dělníky, nepodařilo se jí udělat z dělníků studenty.“35

Previerková akcia na slovenských vysokých školách zo začiatku roku 1949, eufemisticky označovaná ako „demokratizácia“, však so sprístupňovaním vzdelania širokej verejnosti nemala nič spoločné. V skutočnosti išlo o študijnú, no najmä politickú čistku s negatívnym efektom, nie o otváranie vysokých škôl uchádzačom z predtým údajne znevýhodneného prostredia. $V$ dôsledku previerok boli zo štúdia dočasne alebo trvalo vylučovaní poslucháči, ktorí nespíňali požiadavky študijnej úspešnosti a/alebo politickej lojálnosti, a to na základe rozhodnutí previerkových komisií, organizovaných fakultami v spolupráci so straníckym aparátom. Termín „demokratizácia“ sa napriek tomu používal s úplnou samozrejmostou: v súvislosti s touto vlnou čistiek medzi vysokoškolskými študentmi ide o klúčové slovo všetkých

33 Pozri CONNELLY, J.: Zotročená univerzita, s. 417. Predstavitelia režimu sa snažili zatraktívnit vysokoškolské štúdium pre týchto občanov a vytvorił tak novú, lojálnu elitu rôznymi spôsobmi, predovšetkým organizovaním špeciálnych kurzov na prípravu pracujúcich, podporou ich štúdia popri zamestnaní a zvýhodňovaním týchto uchádzačov pri prijímacom konaní na vysokoškolské štúdium.

34 Slovenský národný archív, Bratislava (d’alej SNA), fond (f.) Sekretariát Ústredného výboru Komunistickej strany Slovenska (ÚV KSS - sekretariát), škatula (šk.) 153, záznam zo zasadnutia sekretariátu 24.5.1957, Informatívna správa o výsledkoch plnenia politickej smernice zlepšit triedne zloženie na vysokých školách.

35 CONNELLY, J.: Zotročená univerzita, s. 395. 
dobových slovenských archívnych materiálov. ${ }^{36}$ Študenti a študentky, ktorí previerkou neprešli, boli dokonca označovaní poznámkou „vydemokratizovaný/-á““. Pravdepodobne preto, že išlo o prvú vel'kú čistku na slovenských vysokých školách, sa termín „demokratizácia“ natolko vžil, že sa neskôr v slovenskom akademickom prostredí občas mylne používal aj na označenie iných čistiek a previerok. ${ }^{37}$ Termín "demokratizácia“ ako označenie študentskej čistky je pritom slovenským špecifikom. V českej časti republiky sa síce na začiatku tiež používal, ${ }^{38}$ no v praxi sa táto čistka (taktiež eufemisticky) nazývala najmä studijní prověrka, čo malo upriamit pozornost na jej zdanlivo nepolitický rozmer. ${ }^{39}$

\section{Rámec a priebeh „študijnej previerky“ $v$ Československu}

Procedúra preverovania študujúcich, ktorá zahŕňala povinné vypíňanie dotazníkov, následné lustrácie jednotlivých osôb prostredníctvom miestnych národných výborov a ústne pohovory, nebola pri „demokratizačnej akcii“ novinkou. Prvé preverovanie vysokoškoláci na Slovensku zažili už v rokoch 1945 a 1946 pri previerke politickej a národnej spolahlivosti. ${ }^{40}$

Študenti a študentky vysokých škôl už mali skúsenost̉ aj s vyslovene politickou čistkou v podobe činnosti akčných výborov v prvej polovici roka 1948. V ich dôsledku bolo na Slovensku „vyakčnených“ okolo tridsat vysokoškolákov, ktorých stranícke orgány označili ako „popredných predstavitel’ov reakčného študentstva“. ${ }^{41}$ Sociálne, no najmä politicky však zostávalo zloženie vysokoškolského študentstva predstavám komunistov vzdialené. V druhej polovici roku 1948 tak vznikla myšlienka „študijnej

36 SNA, f. ÚV KSS - sekretariát, šk. 2, záznam zo zasadnutia sekretariátu 2.3.1949, Správa o priebehu demokratizácie vysokých škôl; tamže, Správa Vysokoškolského výboru KSS na zasadnutie sekretariátu ÚV KSS dňa 28. 3. 1949. Rovnako vyznievajú všetky d’alšie dokumenty týkajúce sa tejto previerky v Slovenskom národnom archíve a články v študentskom časopise Borba.

37 Archív Slovenskej technickej univerzity, Bratislava (d’alej A STU), f. Rektorát, šk. 123, Zoznam demokratizovaných študentov na Fakulte architektúry a pozemného stavitel'stva v Bratislave v šk[olskom] roku 1950/51 pri pohovoroch pred zápisom z 9. 2. 1952. V skutočnosti vtedy už išlo o inú previerku, organizovanú v súvislosti s kampaňou proti „buržoáznemu nacionalizmu“" na jeseň 1950.

38 Pozri URBÁŠEK, P. - PULEC, J.: Vysokoškolský vzdělávací systém v letech 1945-1969, s. 96 (pozri pozn. 5).

39 JAREŠ, J.: „Indiferentní - možnost převýchovy!“, s. 20, pozn. 1 (pozri pozn. 11).

40 Podl'a zloženia otázok v previerkovom formulári sa zdá, že v prvej vlne tejto previerky (1945) sa väčší dôraz kládol na politickú spol’ahlivost', kým v druhej vlne (1946) na spolahlivoste národnú.

41 CHALUPECKÝ, Ivan: K perzekúcii študentov a ich vylučovaniu zo škôl v rokoch 1945-1956. In: Historický zborník, roč. 12, č. 1-2 (2002), s. 137-142, tu s. 139. Podrobnejšie pozri GLOSSOVÁ, Marta: Previerky a vylučovanie študentov slovenských vysokých škôl v rokoch 1948-1960 ako prostriedok výchovy lojálnych elít. Dizertačná práca, obhájená na Filozofickej fakulte Univerzity Komenského v Bratislave v roku 2019. 
previerky“, ktorá oficiálne mala identifikovat a potrestat takzvaných večných študentov, v skutočnosti však mala charakter „„rrídních a politických čistek““42

„Študijnú previerku“ na celoštátnej úrovni vyhlásilo Ministerstvo školstva, vied a umení Československej republiky výnosom č. A 235.271/48-V/41 z 30. novembra 1948. Zaviedlo ním „možnost vyloučit ze studia posluchače, kteří údajně zneužívají svobody studia, nestudují vůbec nebo se bez vážné př́činy ve studiu nápadně zpožd’ují “. ${ }^{43}$ Dňa 6 . decembra 1948 bol výnos doplnený ministerskou smernicou č. A.242.245/48-V/1, ktorá určovala harmonogram previerky a vydávala konkrétne pokyny pre prácu preverovacích komisií. Ministerstvo do nich na návrh Ústredného akčného výboru Národného frontu na vysokých školách menovalo pre každú fakultu trojčlennú komisiu, ktorú spravidla tvoril jeden zástupca profesorského zboru a dvaja študenti. Týmto hlavným fakultným komisiám podliehali subkomisie, ktoré už boli zvyčajne študentské ${ }^{4}$ a ktoré uskutočňovali samotné pohovory s preverovanými. Subkomisie navrhovali fakultné akčné výbory, schvaloval ich Ústredný akčný výbor Národného frontu na vysokých školách a na záver ich potvrdzovalo ministerstvo školstva. Ústredný akčný výbor Národného frontu na vysokých školách mal tiež rozhodujúce slovo pri stanovení cielov previerky a sledovaných parametrov. Popri oficiálnych výnosoch a smerniciach ministerstva vydal pre členov komisií v januári 1949 „Politické smernice pre prácu akčných výborov a hlavných komisií v študijnej previerke“, ktorými sa táto akcia v skutočnosti riadila. ${ }^{45}$

Na českých vysokých školách sa táto studijní prověrka začala ešte v závere roka 1948. Medzi 10. a 15. decembrom si všetci študenti a študentky na dekanátoch svojich fakúlt museli vyzdvihnút rozsiahly dotazník, ktorý mali vyplnit a odovzdat do 18. decembra. Tí, ktorí si dotazník nevyzdvihli alebo ho neodovzdali, boli zo štúdia automaticky vylúčení. Od 15. januára do 10. februára boli následne všetci študujúci postupne predvolávaní na pohovor pred príslušnú subkomisiu, ktorá mala s každým z nich uskutočnit tridsatminútový rozhovor. Výsledky pohovorov boli vyhlásené do dvoch dní. Preverení študenti a študentky do indexu dostali potvrdenie a mohli pokračovat v štúdiu, nepreverení sa mohli do 19. februára 1949 odvolat $\mathrm{k}$ fakultnej hlavnej preverovacej komisii alebo následne $\mathrm{k}$ ústrednej odvolacej komisii, ktorá pozostávala zo zástupcov ministerstva školstva, krajského výboru KSČ, Vysokoškolského výboru KSČ a Ústredného akčného výboru Národného frontu na vysokých školách.

Aké boli výsledky „„študijnej previerky“ na vysokých školách v Čechách a na Morave? Jakub Jareš uvádza ako príklad Filozofickú fakultu Karlovej univerzity, na ktorej bolo z celkového počtu 3748 preverovaných študentov a študentiek vylúčených 435 poslucháčov a d’alších pätsto si nevyzdvihlo dotazník, respektíve sa nedostavilo na pohovor s preverovacou komisiou. Celkovo tak malo z fakulty odíst 935 študujúcich, čo predstavovalo takmer celú štvrtinu. Tento podiel sa blíži

42 JAREŠ, J.: „Indiferentní - možnost převýchovy!“, s. 28.

43 Tamže.

44 Tamže, s. 29.

45 Tamže, s. 33, pozn. 36. 
k celkovému priemeru vylúčených študentov a študentiek na českých a moravských vysokých školách (25,7 percent). Celkové výsledky za české a moravské vysoké školy zhrnuje nasledujúca tabulka $1 .{ }^{46}$

Tab. 1: Výsledky „„̌tudijnej previerky“ na českých a moravských vysokých školách

\begin{tabular}{|l|r|}
\hline Previerkou prešlo & 39669 študujúcich \\
\hline Počet preverených & 28847 študujúcich \\
\hline Počet nepreverených & 7765 študujúcich \\
\hline Nedostavilo sa, zo štúdia vystúpilo & 2438 študujúcich \\
\hline Percentuálny úbytok & $25,7 \%$ študujúcich \\
\hline
\end{tabular}

\section{Organizácia „demokratizačnej akcie“}

Hoci Komunistická strana Slovenska bola formálne len územnou organizáciou KSČ na Slovensku, ich postup nebol vždy totožný. Príkladom paralelného, no zároveň značne odlišného riešenia rovnakej situácie na Slovensku a v Čechách je „demokratizácia“ a „študijná previerka“ zo začiatku roku 1949.

Kým na českých vysokých školách bol výkonným orgánom Ústredný akčný výbor Národného frontu na vysokých školách a Vysokoškolský výbor KSČ mal pravdepodobne len kontrolnú úlohu, ${ }^{47}$ na Slovensku „demokratizáciu“ prakticky uskutočňoval práve Vysokoškolský výbor KSS. Referentkou pre „demokratizáciu“ bola študentka medicíny Darina (Daria) Beláčková (neskôr Zacharová), po nej agendu prevzal Vladimír Čech, študent právnickej fakulty a neskorší osobný tajomník predsedu slovenských komunistov Viliama Širokého. Hoci na českých vysokých školách sa previerka začala uskutočňovat už na konci roku 1948 a jej ukončenie bolo naplánované na 15. február 1949, na Slovensku bola situácia odlišná. Vysokoškolský výbor KSS konštatoval, že pre nedostatok „kádrov“ „,v dôsledku zmeny v štruktúre vysokoškolského okresu ${ }^{48}$ a oneskoreného straníckeho preverovania" nie je schopný tieto dve akcie (vysokoškolskú previerku a stranícku previerku) zvládnut súčasne. ${ }^{49}$

Pri spomínanom straníckom preverovaní išlo o prvú z dvoch previerok v radoch vládnucej strany, ktoré sa v Československu uskutočnili v rokoch 1948 a 1950.

46 Pozri URBÁŠEK, P. - PULEC, J.: Vysokoškolský vzdělávací systém v letech 1945-1969, s. 100.

47 Pozri JAREŠ, J.: „Indiferentní - možnost převýchovy!“, s. 28, pozn. 27.

48 Vysokoškolský výbor KSS bol v rámci štruktúry verejnej správy postavený na úroveň okresu (resp. okresného výboru). Tento stav platil do roku 1952, ked' bol „vysokoškolský okres“ zrušený a vysokoškolské odbory, zastrešujúce základné organizácie strany na fakultách, boli podriadené organizáciám strany na mestskej úrovni. (SNA, f. ÚV KSS - sekretariát, šk. 30, Správa o práci Vysokoškolského výboru KSS v Bratislave a Košiciach, 2.2.1952.)

49 Tamže, šk. 2, záznam zo zasadnutia sekretariátu ÚV KSS 2.3.1949, Správa VV KSS o priebehu demokratizácie slovenských vysokých škôl. 
Na Slovensku boli jej výsledky vel’mi radikálne, ked’ úplne kladne nebola preverená takmer polovica členstva strany. ${ }^{50} \mathrm{Na}$ vysvetlenie rozporu medzi priebehom študentskej čistky, ktorý bola na Slovensku v porovnaní s českými vysokými školami v konečnom dôsledku miernejšia, a na pohlad ovela prísnejšej previerky členstva Komunistickej strany Slovenska treba poznamenat, že v tomto druhom prípade išlo najmä o administratívny úbytok: čiastočne preto, že KSS viedla členov, ktorí sa prestahovali do českej časti republiky alebo (hlavne v okolí Ostravy) pracovali v závodoch, a pri previerke bolo toto dvojité vykazovanie členstva zrušené, no najmä kvôli fenoménu „ilegálneho opustenia“ strany, ku ktorému „docházelo při změnách bydliště a pracoviště a při odchodech do důchodu, kdy se sice takoví 'komunisté' ze své původní stranické organizace odhlásili, ale do jiné se již nepřihlásili a chovali se, jako by nikdy v komunistické straně organizováni nebyli“ “. ${ }^{11}$ Jiří Mañák počet takýchto ilegálnych odchodov zo strany v rámci celého Československa za roky 1948 až 1951 vyčísluje až na šestsstopätdesiat až sedemsto tisíc, pričom na Slovensku bol administratívny úbytok štyrikrát vyšší než v Čechách a na Morave. Zdanlivo drastické výsledky straníckej previerky na Slovensku v porovnaní $\mathrm{s}$ výsledkami študentskej previerky tak v mnohých prípadoch nespôsobila skutočná čistka, ale skôr upratovanie v neporiadnych straníckych evidenciách. Kvôli prebiehajúcej straníckej previerke teda predstavitelia Vysokoškolského výboru KSS začiatok „očisty“ vysokých škôl posunuli o jeden mesiac a školskej komisii Ústredného výboru KSS zároveň predložili návrh na realizáciu celej akcie, prispôsobený slovenským potrebám. „Demokratizácia“ mala pozostávat z dvoch fáz: v prvej sa mali odstránit z vysokých škôl tí, ktorí neštudujú, a v druhej ich mali nasledovat otvorení odporcovia režimu.

Povereníctvo školstva, vied a umení bolo formálnym garantom celej akcie a malo zaistit jej plynulý priebeh ako po finančnej stránke, tak zaistením „plnej podpory vysokoškolských úradov". ${ }^{52}$ Vylučovanie študentov a študentiek sa totiž dialo mimo zákonného rámca. V ideologickom chápaní „opatrenia urobené po roku 1948 legalizoval a vysokoškolské štúdium v zmysle ustanovení Košického vládneho programu reformoval a demokratizoval až nový zákon o vysokých školách číslo 58/1950 Zb. z 18. mája 1950 “. ${ }^{53} \mathrm{~V}$ skutočnosti však tieto čistky boli protiprávne tak či tak, už len z dôvodu uplatňovaného princípu retroaktívnosti, nehovoriac o vágnych pravidlách a možnostiach na odvolanie, ktoré dávali velký priestor svojvôli členov previerkových komisií.

„Demokratizácia“ na Slovensku oficiálne začala prejavom povereníka školstva Ladislava Novomeského pri príležitosti nástupu do prvej pätročnice dňa 14. januára 1949.

50 Pozri MAŇÁK, Jiří: Proměny strany moci: Studie a dokumenty k vývoji Komunistické strany Československa v období 1948-1968, zv. 1. Praha, Ústav pro soudobé dějiny AV ČR 1995, s. 15 n. a 79-99.

51 Tam̌̌e, s. $15 \mathrm{n}$.

52 SNA, f. ÚV KSS - sekretariát, šk. 2, Správa VV KSS o priebehu demokratizácie slovenských vysokých škôl, 2.3.1949.

53 ČERVINKA, Ján: Vývin vysokých škôl. In: KOTOČ, Ján a kol.: Slovenské školstvo po oslobodení. Bratislava, Slovenské pedagogické nakladatel'stvo 1970, s. 105. 


$$
\text { /- Odpis ormigom roznnož. listu-/ }
$$

\section{Disciplinárna komísia na preskúmanie študijného prospechu poslucháčov/absolventov Svङo}

V Bratislave 28.3.1949

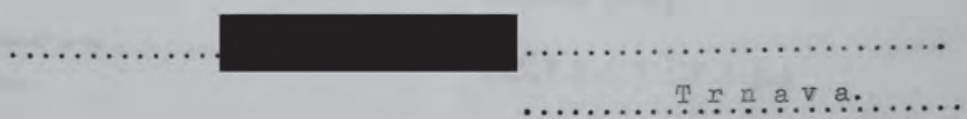

Disciplinárna komísia Ta pozýva na preverovací rozhovor, ktorý

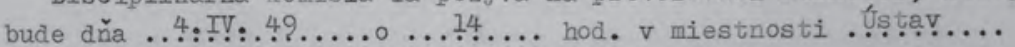
j.̣azykov. .svšo.

Bezpodmienenčne treba predložit' tieto doklady:

l/ index a všetky vysvedćenia,

2/ pracovný zápisník,

3X legitimácia Tu,

4/ pracovný preukaz alebo iný d dklad o zamestnaní, ak sa na zamestnanie odvolávaš,

$5 /$ potvrdenie zo sanatória, a ebo nemeocnice, ak sa na tieto odvolávaš,

6/ ostatné doklady, ktorými chceš dokázat závažné skutočnosti, ktoré môžu ovplyvnit̀ výsledok preverovania.

Nedostavenie sa v stanovenom čase bez predchádzajúceho písomného ospravedlnenia / len z vel’ni záva zných đôvodov/ Q́ude mat za následok vylúčenie zo svšo.

Disciplinárna komisia na preskúmanie študijného prospechu poslucháčov / absolventov/ SvŠo.

Odpis štandardizovaného pozvania študenta Vysokej školy hospodárskych vied na preverovací pohovor (Archív Ekonomickej univerzity v Bratislave, fond Rektorát) 
Hlavné zásady preverovania boli súčasne publikované v študentskej tlači. Predseda Vysokoškolského výboru KSS Timotej Turský, študent medicíny a neskorší profesor, v článku „Demokratizácia vysokých škôl“ z 15. januára 1949 v časopise Slovenského sväzu mládeže $B o r b a^{54}$ začínajúcu akciu zdôvodňoval tým, že sa zatial neurobili žiadne kroky na zmenu zloženia vysokoškolského študentstva, pričom súčasný stav vraj nezodpovedá novému spoločenskému poriadku. Vo svojom článku spomenul oba plánované nástroje údajnej demokratizácie štúdia: nástup pracujúcich na vysoké školy aj „očistu“ vysokoškolského študentstva. Podrobne sa však venoval len aktuálnej otázke „očisty“. „Paraziti“, „povalači a šmelinári“, „flákači a cudzopasníci“, ktorých bolo podla jeho odhadu na vysokých školách tridsat až štyridsat percent, mali byt zo štúdia nemilosrdne vylúčení, takže „konečne sa bude môcť prestat dívat? robotník, rol'ník na vysokoškolákov s nedôverou. (...) Chceme dosiahnut', aby ked' sa povie vysokoškolák, sa rozumelo: usilovne sa vzdelávajúci, uvedomelý, l’udu oddaný mladý človek. " ${ }^{55} \mathrm{~V}$ ten istý deň, 15 . januára 1949, poslalo povereníctvo školstva slovenským vysokým školám inštrukcie o dotazníkoch, ktoré mali tieto školy rozdat’ a následne vyzbierat’ od všetkých študentov a študentiek.

O niekol'ko dní neskôr, 21. januára 1949, poslalo povereníctvo školstva vysokým školám pokyn na preskúmanie študijného prospechu ich poslucháčov a absolventov. Potrebu preverit prospech študentov a študentiek zdôvodňovalo platnými disciplinárnymi poriadkami, podla ktorých majú vysoké školy povinnost̉ zabránit zneužívaniu slobody štúdia. Podla týchto smerníc mali disciplinárne komisie „v závažných prípadoch vylúčit zo štúdia na vysokých školách poslucháčov, ktorí si neplnia svoje študijné povinnosti“, pričom vylúčenie malo nadobudnút platnost̉ až po potvrdení povereníctvom, ktoré si tak vyhradilo „právo pokračovat' vo svojej vlastnej kompetencii voči týmto študentom a absolventom".${ }^{56}$

Za samotnú akciu boli formálne zodpovedné dekanáty fakúlt. Politický dohlad nad ňou i jej technickú realizáciu však mali na starosti pre tento účel vytvorené preverovacie komisie: pre každú fakultu povereníctvo školstva na návrh Vysokoškolského výboru KSS vymenovalo štvorčlennú hlavnú preverovaciu komisiu, na ktorej činnost mala dohliadat fakultná základná organizácia komunistickej strany, čo jej zaručovalo politickú kontrolu na straníckej úrovni. Každá komisia pozostávala z jedného zástupcu profesorského zboru, jedného člena povereníctva a jedného študenta, pričom predsedom bol spravidla predseda základnej organizácie KSS na danej fakulte. Úlohou týchto komisií bolo navrhnút povereníctvu trojčlenné subkomisie, ktoré mali

54 Časopis Borba vychádzal od roku 1947 do roku 1950 (s dvojtýždennou alebo mesačnou periodicitou), pôvodne ako orgán nekomunistického Sväzu vysokoškolského študenstva, strešnej organizácie študentských spolkov na Slovensku. Na jeseň 1947 však komunistickí študenti získali v SVŠ väčšinu, po februári 1948 bol začlenený do komunistického Slovenského sväzu mládeže a Borba sa stala tlačovým orgánom SSM. K začiatku roku 1951 bola zlúčená s časopisom Smena. (V dobovom slovenskom pravopise sa oproti súčasnosti písali odlišne slová „sväz“ a „študenstvo“.)

55 TURSKÝ, Timotej: Demokratizácia vysokých škôl. In: Borba, roč. 3, č. 2 (15.1.1949), s. 3.

56 Archív Univerzity Komenského, Bratislava (d’alej AUK), f. Rektorát UK I., šk. 16, Dotazníková akcia. 
uskutočňovat’ samotné pohovory, vypracovat študijné normy (takzvaný minimálny študijný prospech), ktoré boli východiskom pre študijné preverovanie, ${ }^{57}$ kontrolovat a vyhlasovat výsledky preverovania. Subkomisie pozostávali zo študentov, no ich počet zrejme nebol fixný. ${ }^{58}$ Predsedníctvo Vysokoškolského výboru KSS vytvorilo na základe „prehladu o celkovej situácii na jednotlivých fakultách a o potrebách nášho hospodárskeho života" aj akýsi numerus clausus vylúčených poslucháčov pre jednotlivé fakulty a vysoké školy, ${ }^{59}$ ako to registruje nasledujúca tabulka 2.

Tab. 2: Predpokladaný počet vylúčených študentov a študentiek podla Vysokoškolského výboru KSS

\begin{tabular}{|l|r|r|}
\hline Lekárska fakulta SU & $15 \%$ & t.j. asi 230 \\
\hline Právnická fakulta SU & $40 \%$ & 640 \\
\hline Filozofická fakulta SU & $10 \%$ & 40 \\
\hline Prírodovedecká fakulta SU & $30 \%$ & 120 \\
\hline Farmaceutická fakulta SU & $10 \%$ & 10 \\
\hline Pedagogická fakulta SU & $50 \%$ & 650 \\
\hline Slovenská vysoká škola obchodná*** & $10 \%$ & 250 \\
\hline Slovenská vysoká škola technická & &
\end{tabular}

* Takto stanovený odhad „únosného počtu“ vylúčených študentov a študentiek filozofickej fakulty by mohol zodpovedat predstave o tejto fakulte ako ideologicky zvlášt exponovanej škole. Skutočné výsledky čistky na filozofickej fakulte však túto hypotézu nepotvrdzujú.

** V roku 1949 došlo k premenovaniu tejto školy zo Slovenskej vysokej školy obchodnej na Vysokú školu hospodárskych vied.

\section{Prváfáza - zhromaždovanie dotazníkov}

V dňoch 18. až 25. januára 1949, teda o mesiac neskôr než na českých vysokých školách, si všetci vysokoškoláci na Slovensku museli na príslušnom dekanáte vyzdvihnút a následne odovzdat vyplnený dotazník. ${ }^{60}$ Prevzatie aj odovzdanie vyplneného

57 Tamže, Preskúmanie študijného prospechu študentov/absolventov všetkých slovenských vysokých škôl.

58 Platili zásady, že po absolvovaní prvého ročníka môže poslucháč či poslucháčka v skúškach vymeškat jeden semester, do prvej štátnice jeden rok, od prvej štátnice do „absolutória“ jeden rok a po absolutóriu dva až tri roky. Fakulty však mohli postupovať podla vlastných špecifických potrieb.

59 „Bola to asi pätčlenná komisia poslucháčov z nižších ročníkov, ktorých som poznal len z videnia," uviedol v neskoršej žiadosti o rehabilitáciu napr. jeden študent (Archív Ekonomickej univerzity v Bratislave (d’alej A EUBA), f. Rektorát, sekretariát rektora, šk. 42, žiadosť o rehabilitáciu študenta Vysokej školy hospodárskych vied Vojtecha O).

60 Vzor samotného dotazníka sa zatial' nepodarilo nájst'. 


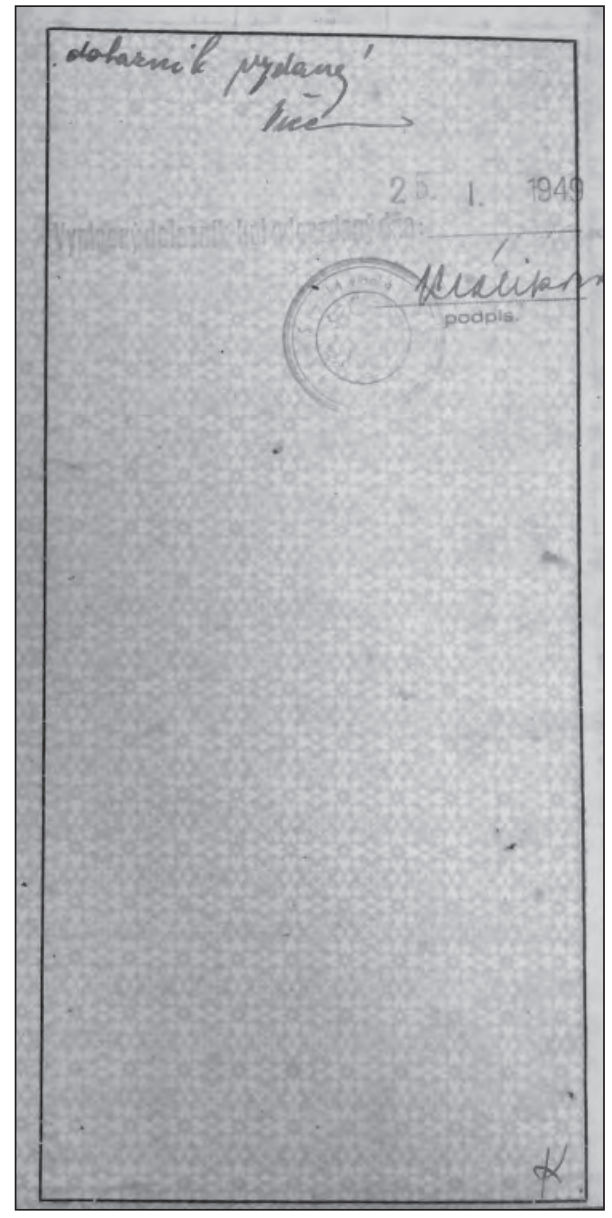

Potvrdenie o prevzatí preverovacieho dotazníka $v$ študentskom indexe. Tento záznam bol podmienkou pre pokračovanie poslucháčov v štúdiu (Archív Ekonomickej univerzity $v$ Bratislave, fond Rektorát) dotazníka bolo na študijnom oddelení poslucháčom vyznačené do indexu. ${ }^{61}$ Pokial' by si dotazník nevyzdvihli alebo ho neodovzdali, mali byt automaticky vylúčení zo štúdia.

V tejto súvislosti je potrebné upozornit na nezvyčajne vysoký počet študentov a študentiek na Právnickej fakulte Slovenskej univerzity (17 percent) a na Fakulte strojného a elektrotechnického inžinierstva Slovenskej vysokej školy technickej (12 percent), ktorí podla správy zo 14. februára 1949 dotazníky k tomuto termínu neodovzdali. ${ }^{62}$ Spolu so študujúcimi, ktorí nesplnili minimálne študijné normy, tak z týchto fakúlt malo byť vylúčených až 37,42 , respektíve 37 percent študentov a študentiek. ${ }^{63}$ Otázkou je, či vysoký počet neodovzdaných dotazníkov, ktorý sa týka len týchto dvoch fakúltt, ${ }^{64}$ bol výsledkom nejakej administratívnej chyby, alebo skutočne taký vysoký počet poslucháčov riskoval automatické vylúčenie, aby nemuseli podstúpit ponižujúce kádrovanie. Niektorí mohli aj špekulovat, že sa hrou na „mŕtveho chrobáka“"vyhnú preverovaniu, ako to (pri inej príležitosti) opisoval jeden študent vo svojej žiadosti o rehabilitáciu: „Nový index odňali mi dvakrát (na jar 1949 a v júni 1950 - pozn. autorky) na prešetrenie a dvakrát vrátili s tým, že je všetko v poriadku. V roku 1950 (pri zápise na akademický rok 1950/1951 - pozn. autorky) povedal

61 A EUBA, f. Rektorát, sekretariát rektorátu, šk. 41, žiadost o rehabilitáciu študenta VŠHV Viliama O.

62 SNA, f. ÚV KSS - sekretariát, šk. 2, Správa VV KSS o priebehu demokratizácie slovenských vysokých škôl. Správa bola schválená 14. februára 1949 a na rokovanie organizačného výboru ÚV KSS bola predložená 2 . marca 1949.

63 Pozri nasledujúci tabul'ku 3.

64 Správa Vysokoškolského výboru KSS z 2. marca 1949 menovite uvádza počet neodovzdaných dotazníkov len pri týchto dvoch fakultách, v prípade ostatných desiatich fakúlt tento údaj chýba. 
mi Ing. Š. (ktorý bol asistentom u prof. Králička), že videl môj kádrový materiál z Lučenca, ktorý je taký nepriaznivý, že je vylúčené, aby som mohol na škole ostat. Preto mi radil, aby som sa pred preverovaciu komisiu nedostavil, lebo budem zbytočne pokorovaný. (...) Ja som školu navštevoval nad’alej v nádeji, že moja žiadost? na povereníctve školstva bude kladne vybavená. V auguste 1951 som však musel nastúpit do zamestnania, pretože som sa nemohol preukázat štúdiom ani zamestnaním a hrozilo mi zavedenie trestného pokračovania."“5

V niektorých prípadoch však táto stratégia mohla byt aj úspešná, ako to zažil Július Porubský: „Bol som vedúcim krúžku. (...) Potom bol vyhlásený termín previerok a Máňa B., ideologická vedúca krúžku, prišla za mnou a vyhlásila, že do preverovacej komisie budem aj ja zaradený. (...) Ja, ktorý som chodil miništrovat', chodil do Katolíckej kancelárie atd', som mal preverovat svojich kolegov... Vyhovoril som sa na zhoršené zdravie svojich rodičov, ktorých som práve v deň previerok musel navštívit. A tak sa stalo, že som na niekolko dní urýchlene odišiel domov. Unikol som previerkam. Potom jednoducho zabudli na to, že som sa im nepodrobil.“66

Zdá sa však, že neskôr organizátori zámer vylúčit poslucháčov kvôli neodovzdaným dotazníkom prehodnotili, respektíve poskytli im možnost’ odovzdat vyplnené dotazníky po termíne, ked’že v prehladoch vylúčených poslucháčov z neskorších dátumov už takéto vysoké čísla nefigurujú. ${ }^{67}$

Po vyhodnotení odovzdaných dotazníkov boli študenti a študentky rozdelení do troch kategórií:

1. vyhovujúci podmienkam poberania štipendia;

2. spíňajúci študijné normy, no bez nároku na štipendium;

3. nespíňajúci ani minimálne študijné normy. ${ }^{68}$

Hlavné preverovacie komisie následne vypracovali zoznam študentov a študentiek spadajúcich do tretej skupiny, teda kandidátov na vylúčenie zo študijných dôvodov. Ich podiel na jednotlivých fakultách Slovenskej univerzity a Slovenského vysokého učenia technického a na Slovenskej vysokej škole obchodnej (respektíve Vysokej škole hospodárskych vied) zaznamenáva nasledujúca tabulka 3:

65 A EUBA, f. Rektorát, sekretariát rektorátu, šk. 41, žiadosť o rehabilitáciu študenta VŠHV Vojtecha K.

66 PORUBSKÝ, Július: V službách Katolíckej akcie. In: TAKÁČ, Ladislav - LESŇÁK, Rudolf LAZAR, Ján (ed.): Zločiny komunizmu na Slovensku 1948-1989, zv. 2. Prešov, Vydavatel'stvo Michala Vaška 2001, s. 304. Július Porubský úspešne ukončil štúdium na Právnickej fakulte UK v roku 1950 a bol prijatý na miesto asistenta, v tejto pozícii pôsobil jeden rok. Nasledujúci rok však bol zatknutý, v roku 1955 odsúdený za činnost v Katolíckej akcii a väznený v Jáchymove.

67 Do úvahy prichádza aj hypotéza, že sa niektorí študujúci na právnickej a strojno-elektrotechnickej fakulte rozhodli demonštratívne kolektívne neodovzdat dotazníky. To sa však doteraz na základe archívnych prameňov nepodarilo potvrdit a ako pravdepodobnejšie sa zdá vysvetlenie, že dotyční boli nedochvílni a dotazníky odovzdávali až po termíne.

68 AUK, Rektorát UK I., šk. 16, Preskúmanie študijného prospechu študentov/absolventov všetkých slovenských vysokých škôl. 
Tab. 3: Podiel študujúcich navrhnutých na vylúčenie na jednotlivých školách po preskúmaní študijných výsledkov (v percentách) ${ }^{69}$

\begin{tabular}{|l|r|}
\hline Filozofická fakulta SU & 16,70 \\
\hline Prírodovedecká fakulta SU & 15,00 \\
\hline Právnická fakulta SU & 20,17 \\
\hline so započítaním neodovzdaných dotazníkov (17\%) & 37,42 \\
\hline Pedagogická fakulta SU & 16,00 \\
\hline Farmaceutická fakulta SU & 15,00 \\
\hline Lekárska fakulta SU & 23,00 \\
\hline Slovenská vysoká škola obchodná & 36,00 \\
\hline Odbor špeciálnych náuk SVŠT & 10,80 \\
\hline Odbor strojného a elektrotechnického inžinierstva SVŠT & 25,00 \\
\hline so započítaním neodovzdaných dotazníkov (12\%) & 37,00 \\
\hline Odbor chemicko-technologického inžinierstva SVŠT & 29,00 \\
\hline Odbor inžinierskeho stavitelstva SVŠT & 26,00 \\
\hline
\end{tabular}

\section{Druhá fáza - zber kádrového materiálu v teréne a pohovory}

Odovzdané a preverovacími komisiami vyhodnotené dotazníky sa stali podkladom pre druhú fázu preverovania. Tá spočívala v zhromaždení kádrového materiálu na všetkých študentov a študentiek a v následných pohovoroch. Poslucháči slovenských vysokých škôl boli rozdelení podla okresov ich trvalého bydliska, do ktorých bolo následne vyslaných sedemdesiatpät „kádrových súdruhov“.70 Tí mali po podrobnej inštruktáži v spolupráci s miestnymi a okresnými straníckymi orgánmi získat $\mathrm{k}$ jednotlivým poslucháčom politický materiál. ${ }^{71} \mathrm{Na}$ jeho základe potom boli vysokoškoláci z politického hladiska rozdelení do štyroch skupín, označených písmenami A, B, C, D. ${ }^{72}$ Práve tu vznikol najväčší priestor na zneužitie núkajúcej sa „príležitosti“ na vybavovanie si osobných účtov, ked’že posudok vydaný miestnym národným výborom v mieste bydliska poslucháča bol prakticky jediným podkladom pre previerkovú komisiu a bolo takmer nemožné sa voči jeho obsahu bránit. Na to aj často upozorňovali preverovaní poslucháči vo svojom odvolaní. „Podla mojej mienky môže íst o nepravdivé informácie z miesta môjho bydliska, podávané zaujatými

69 SNA, f. ÚV KSS - sekretariát, šk. 2, Správa o priebehu demokratizácie slovenských vysokých škôl, 2.3.1949.

70 Tamže.

71 Ked’že „kádroví komisári“ mali na zhromaždenie tohto materiálu k tisíckam študentov len niekol'ko týždňov, spôsob získavania informácií a ich kvalita vyvolávajú pochybnosti.

72 Pozri tabul'ku 4. 


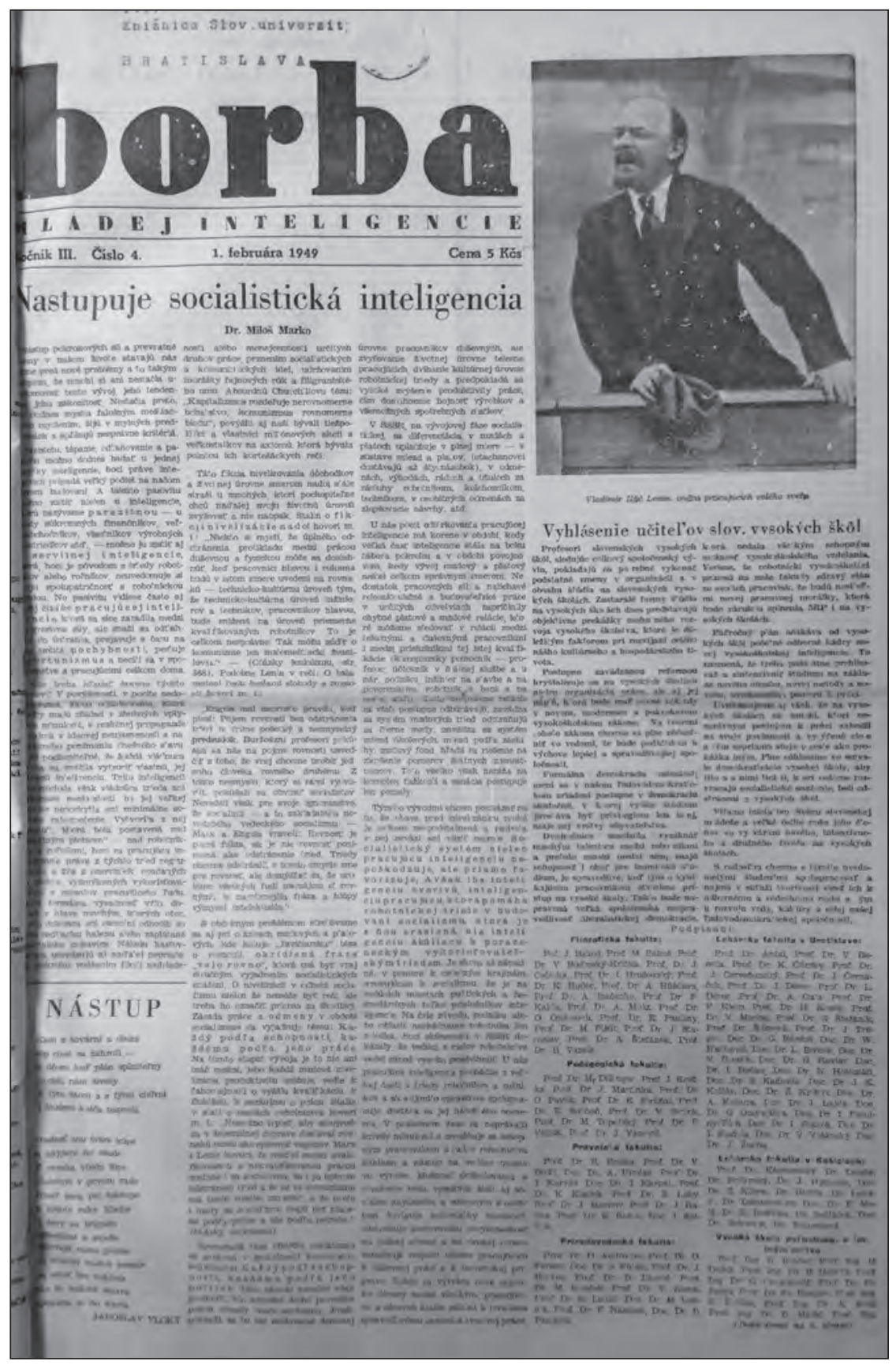

Titulná stránka študentského časopisu Borba z 1. februára 1949, ktorý informoval o priebehu „demokratizácie“ slovenských vysokých škôl 
osobami, “vyjadril sa napríklad jeden z nich. ${ }^{73} \mathrm{~V}$ materiáloch zaznievali skutočne absurdné obvinenia: „Bolo mi dávané za príčinu môjho vylúčenia zo školy, že starý otec niekedy v rokoch 1929-1933 mal na dedine v Terchovej pílu a mal v prenájme farský majetok, "stažoval sa d’alší. ${ }^{74}$ Tento spôsob boja, ked' jednotliví ludia dokázali využit ponúkanú príležitost̉ na poškodenie iných, či už z dôvodu pomsty, alebo snahy o osobné obohatenie či prospech, pričom ideologické floskuly slúžili len ako nepriestrelná zásterka, sa s úspechom používal aj neskôr, a to aj na najvyšších politických úrovniach. Naplno sa rozvinul o niekol'ko mesiacov, ked' vo všetkých krajinách sovietskeho bloku vypukla honba na takzvaných vnútorných nepriatelov.

Na základe predbežných výsledkov z dvadsiatich okresov funkcionári Vysokoškolského výboru KSS odhadovali politické rozvrstvenie študujúcich do jednotlivých skupín takto:

Tab. 4: Politické zloženie študujúcich podla Vysokoškolského výboru KSS ${ }^{75}$

\begin{tabular}{|l|l|r|}
\hline A & „komunisti“ & $11,5 \%$ \\
\hline B & „lojálni“/,indiferentni“** & $49,0 \%$ \\
\hline C & „neuvedomelí odporcovia“ & $16,9 \%$ \\
\hline D & „uvedomelí odporcovia“ & $13,2 \%$ \\
\hline & nezistené & $9,4 \%$ \\
\hline
\end{tabular}

* Pre túto najpočetnejšiu skupinu študentov a študentiek sa v dobovej terminológii používa väčšinou termín „indiferenti“-teda politicky nezaradení, ktorí boli hlavným cielom „ideologickej prevýchovy“. Na tomto mieste použitý termín „lojálni študenti“ teda nezodpovedá realite, ked’že predpokladá vedomý súhlas s oficiálnou ideológiou. V skutočnosti však išlo o študentov, ktorí vyhlasovali, že ich politické otázky nezaujímajú. (K termínu „indiferenti“ pozri JAREŠ, J.: „Indiferentní - možnost převýchovy!“, s. 26, pozn. 23 - pozri pozn. 11.)

Okrem študijného prospechu a politického postoja sa v previerke zistoval aj triedny pôvod a zamestnanie rodičov, účast na brigádach a pol’ahčujúce okolnosti (za tie sa považovali prekonané choroby, starostlivost o rodinu v prípade vydatých študentiek a pod.). Na základe triedneho pôvodu boli študenti rozdelení do troch skupín:

1. „Velkkoburžoázia a slobodné zamestnanie s ročným príjmom nad 200000 Kčs; fabrikanti s podnikom nad 10 zamestnancov, vel'kostatkári s výmerou pôdy väčšou než 25 ha“;

2. „Živnostníci a slobodné zamestnania s ročným príjmom od 80000 Kčs do 200000 Kčs, rolní́ci od 5 do 25 ha“;

3. „najchudobnejší, robotníci, rol’níci do 5 ha“.76

73 A EUBA, f. Rektorát, sekretariát rektora, šk. 41, žiadosť študenta VŠHV Vojtecha O. o rehabilitáciu z 24.6.1968.

74 Tamže, žiadost študenta VŠHV Gustáva O. o rehabilitáciu z 11.3.1969.

75 SNA, f. ÚV KSS - sekretariát, šk. 2, Správa VV KSS o priebehu demokratizácie slovenských vysokých škôl, 2.3.1949.

76 SNA, f. ÚV KSS - sekretariát, šk. 2, Správa VV KSS o priebehu demokratizácie slovenských vysokých škôl, 2.3.1949. 
Podobné delenie vyplynulo aj z kritéria majetku rodičov:

1. majitelia viacerých domov a polí nad 25 ha;

2. majitelia poschodového domu a polí nad 5 ha;

3. majitelia rodinných domov a polí do 5 ha.

Zohladňovalo sa aj kritérium účasti na brigádach, kde do prvej skupiny boli zaradení „úderníci“ a „pochválení účastníci“, do druhej skupiny účastníci brigády na Trati mládeže a do tretej skupiny poslucháči, ktorí sa brigády nezúčastnili alebo dostali negatívny posudok.

Po terénnej práci „kádrových súdruhov“a vyhodnotení získaného materiálu nasledovali pohovory jednotlivých študentov a študentiek s preverovacími subkomisiami. Od previerky na českých vysokých školách sa zásadne líšili v tom, že na pohovor neboli predvolaní všetci poslucháči, ale len tí, ktorí boli na základe dotazníkov a informácií z miestnych a okresných straníckych orgánov zaradení:

1. do 3. skupiny zo študijného hladiska;

2. do kategórie D z politického hladiska;

3. do 2. skupiny zo študijného hladiska a do kategórie $\mathrm{C}$ z politického hladiska, ak pritom spadali podla triedneho pôvodu do 1. skupiny a brigád sa nezúčastnili alebo mali negatívny posudok (3. skupina).

Tab. 5: Počet študujúcich predvolaných na pohovor a nepreverených po pohovore na jednotlivých slovenských školách ${ }^{77}$

\begin{tabular}{|c|c|c|c|}
\hline Škola & 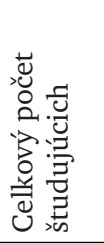 & 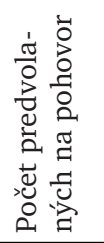 & 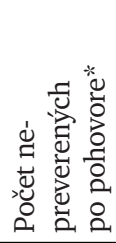 \\
\hline Právnická fakulta SU & 1392 & 543 & 105 \\
\hline Filozofická fakulta SU & 723 & 163 & 9 \\
\hline Pedagogická fakulta SU & 182 & 30 & 4 \\
\hline Prírodovedecká fakulta SU & 426 & 65 & 2 \\
\hline Lekárska fakulta SU & 2004 & 628 & 165 \\
\hline Farmaceutická fakulta SU & 347 & 73 & 8 \\
\hline Vysoká škola hospodárskych vied & 1445 & 519 & 180 \\
\hline Vysoká škola pol'nohospodárskeho a lesného inžinierstva & 737 & 182 & 52 \\
\hline Odbor chemicko-technologického inžinierstva SVŠT & 579 & 159 & 37 \\
\hline Odbor strojného a elektrotechnického inžinierstva SVŠT & 1101 & 312 & 41 \\
\hline
\end{tabular}

77 Tamže, Správa Vysokoškolského výboru KSS na zasadnutie sekretariátu ÚV KSS dňa 28.3.1949, príloha 1 . 


\begin{tabular}{|l|r|r|r|}
\hline Odbor inžinierskeho stavitel'stva SVŠT & 637 & 221 & 44 \\
\hline Odbor špeciálnych náuk SVŠT & 230 & 22 & 4 \\
\hline SPOLU & 9802 & $\mathbf{2 9 1 7}$ & $\mathbf{6 5 1}$ \\
\hline
\end{tabular}

* Tento počet nepreverených bol ešte navýšený o prípady poslucháčov, ktorí si vôbec neprevzali preverovací dotazník (pozri tabul'ku 4). Zároveň však nejde o definitívnu sumu nepreverených študujúcich, ked’že ich počet sa neskôr významne znížil po zásahu odvolacej komisie (pozri tabulku 7).

Oficiálne platilo, že predvolanie na pohovor malo takmer s istotou znamenat vylúčenie zo štúdia: „Zásadne len vo výnimočných prípadoch môžu rozhovory zmenit vopred utvorené rozhodnutie, " konštatovalo sa vo správe Vysokoškolského výboru KSS o priebehu previerok. ${ }^{78}$ Pohovory tak mali mat skôr „výchovný“" charakter: „Dokáže sa poslucháčovi, že nie je schopný navštevovat vysokú školu, a poukáže sa na jeho nemorálnost a nezodpovednost' voči štátu a rodičom ... dokáže sa mu, že lajdačil a neštudoval. (...) ...musí vysvetlit, ako chápe svoje štúdium z hladiska spoločenského, čo doteraz pre štát urobil.“" ${ }^{\prime \prime 9}$ Ako však vyplýva z nasledujúcej tabul'ky 6 , v praxi boli verdikty preverovacích komisií omnoho miernejšie a väčšina pohovorov skončila „preverením s podmienkami“, čo znamenalo, že po ich splnení (napríklad v prípade študijných podmienok) mohol dotyčný bez prerušenia pokračovat’ $\mathrm{v}$ štúdiu.

Administratívny postup spočíval v písomnom predvolaní poslucháčov dekanátom a následnom odobratí indexov. Tí, ktorí preverovaním prešli úspešne, do indexu dostali špeciálnu klauzulu, bez ktorej bol index neplatný. Vylúčení poslucháči nedostali žiadne oficiálne rozhodnutie a často sa o svojom vylúčení dozvedeli len náhodou: „O vylúčení som sa dozvedel vtedy, ked’ prof. Krjukovská pýtala po skúške z ruštiny index a ja som ho nemal, povedala, že som teda vylúčený zo štúdia." ${ }^{80}$

Zistenia subkomisií sa využívali aj sekundárne v rámci propagandy. Redaktori študentského časopisu Borba publikovali ukážky z rozhovorov, v ktorých predvolaní poslucháči preukazovali neznalosť základných pojmov a faktov súčasného politického života (napríklad nevedeli vysvetlit skratku STM - Sútaž tvorivosti mládeže - alebo tvrdili, že generálny tajomník ÚV KSČ Rudolf Slánský je predsedom odborových zväzov). Túto politickú neuvedomelost redaktori uštipačne spájali so slabým študijným prospechom. Ako opačný (pozitívny) príklad prezentovali študenta, ktorý síce pochádzal z „velkostatkárskej“ rodiny, a teda dostal pozvanie na pohovor, no konfiškácia otcovho majetku a práca v továrni „vykresali z neho celkom iného človeka", ${ }^{81}$ takže previerkou prešiel úspešne. Tieto reportáže mali smerovat k záveru, že „predsa len tí komunisti nie sú takí hrozní!“.82

78 Tamže, Správa VV KSS o priebehu demokratizácie slovenských vysokých škôl, 2.3.1949.

79 Tamže.

80 A EUBA, f. Rektorát, sekretariát rektora, šk. 41, žiadosť študenta VŠHV Vojtecha O. o rehabilitáciu z 24.6.1968.

81 Zábery zo študijnej previerky. In: Borba, roč. 3, č. 8 (10.4.1949), s. 8.

82 Demokratizácia u filozofov. In: Tamže, s. 8. 


\section{Výsledky „demokratizácie“}

Po vyhodnotení preverovacích dotazníkov a uskutočnení pohovorov boli vyhlásené výsledky „demokratizačnej očisty“ slovenských vysokých škôl. Na základe rozhodnutia Ústredného výboru KSS boli vysokoškoláci rozdelení do piatich skupín:

1. poslucháči preverení bez podmienok ${ }^{83}$

2. poslucháči podmienečne preverení so stanoveným termínom skončenia všetkých predpísaných skúšok ${ }^{84}$ - Do tejto skupiny mohli byt’ zaradení všetci, ktorí politicky spadali do kategórie A (teda označení ako „komunisti“), s výnimkou „niektorých kriklavých prípadov, ktoré sú všeobecne známe - vel’mi zlí študenti“, ${ }^{85}$ respektíve spadali do kategórie B (ako „lojálni/indiferentní“), ak nestratili viac než dva semestre štúdia. Do skupiny podmienečne preverených boli zaradení aj poslucháči, ktorí preukázali pol’ahčujúce okolnosti, t.j. repatrianti, študujúci s lekárskym potvrdením o prekonaní operácie alebo vážnej choroby, zamestnaní s politickou charakteristikou A alebo B a vydaté študentky. Kontrolu podmienečne vylúčených vysokoškolákov mali uskutočňovat fakultné preverovacie komisie vždy v čase vypršania trvania podmienky. ${ }^{86}$

3. poslucháči vylúčení $v$ dôsledku neodovzdania preverovacieho dotazníka ${ }^{87}$-Napokon ich bolo v porovnaní s pôvodným počtom neodovzdaných dotazníkov (pozri tabul'ku 3) podstatne menej, čo nasvedčuje vysvetleniu, že značná čast’ študujúcich odovzdala dotazníky oneskorene a že za tento prehrešok neboli postihnutí. Z dobových správ nie je jasné, či boli poslucháči zaradení do tretej skupiny vylúčení dočasne, alebo natrvalo.

4. poslucháči vylúčení s možnostou návratu po minimálnej lehote jedného roku ${ }^{88}$ - Do tejto skupiny boli zaradení všetci poslucháči, ktorí patrili do tretej študijnej skupiny a z politického hladiska do skupín C a D. Pre týchto študujúcich výsledok preverovania znamenal preradenie „do výroby“ na dva až tri semestre, po ktorých sa mohli opät pokúsit o štúdium na vysokej škole.

5. poslucháči vylúčení natrvalo ${ }^{89}$ - Do tejto kategórie Ústredný výbor KSS svojím rozhodnutím zaradil „účastníkov viacerých protištátnych politických akcií a študentov, u ktorých niet žiadnych predpokladov, že vôbec niekedy doštudujúu“. ${ }^{90}$ V dôsledku činnosti odvolacej komisie, ako aj účelového „znovuprijímania“ vylúčených poslucháčov na štúdium v nasledujúcom roku 1950 sa však v konečnom

83 Pozri tabulku 6, stĺpec C.

84 Pozri tabulku 6, stlpec D.

85 SNA, f. ÚV KSS - sekretariát, šk. 2, Správa VV KSS o priebehu demokratizácie slovenských vysokých škôl, 2.3.1949.

86 Tamže, šk. 7, Konečné výsledky demokratizačnej akcie na slovenských vysokých školách a návrh na niektoré opatrenia, 20.4.1950.

87 Pozri tabul'ku 6, stĺpec E.

88 Pozri tabul'ku 6, stĺpec F.

89 Pozri tabulku 6, stlpec G.

90 Tamže, šk. 2, Správa VV KSS o priebehu demokratizácie slovenských vysokých škôl, 2.3.1949. 
dôsledku rozdiely medzi skupinami 3, 4 a 5 stierajú a nie je možné spolahlivo dosledovat', ktorí z vysokoškolákov boli napokon zo štúdia vylúčení a na ak dlhú dobu. Za výsledok „demokratizačnej akcie“ po fáze pohovorov tak možno považovat súhrnné číslo v stĺpci H nasledujúcej tabullky (pričom percentá sú vyjadrením podielu z celkového počtu študujúcich tej ktorej školy pred preverovaním):

Tab. 6: Výsledky „demokratizácie“ na slovenských vysokých školách po ukončení pohovorov $^{91}$

\begin{tabular}{|c|c|c|c|c|c|c|c|}
\hline A & B & $\mathrm{C}$ & $\mathrm{D}$ & $\mathrm{E}$ & $\mathrm{F}$ & G & $\mathrm{H}$ \\
\hline Škola & 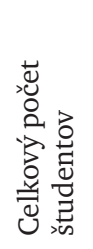 & 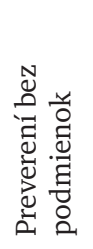 & 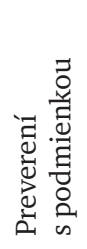 & 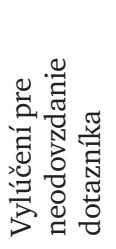 & 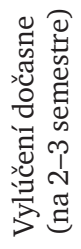 & 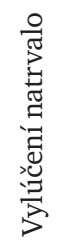 & 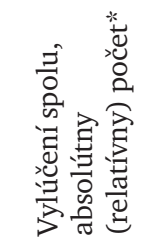 \\
\hline Právnická f. SU & 1392 & 900 & 320 & 67 & 26 & 79 & $\begin{array}{c}172 \\
(12,3 \%)\end{array}$ \\
\hline Filozofická f. SU & 886 & 794 & 83 & 0 & 6 & 3 & $9(1 \%)$ \\
\hline Pedagogická f. SU & 182 & 158 & 20 & 0 & 4 & 0 & $4(2 \%)$ \\
\hline Prírodovedecká f. SU & 426 & 365 & 43 & 16 & 1 & 1 & $18(8 \%)$ \\
\hline Lekárska f. SU & 2004 & 1397 & 369 & 73 & 153 & 12 & $\begin{array}{c}238 \\
(11,8 \%)\end{array}$ \\
\hline Farmaceutická f. SU & 351 & 274 & 65 & 4 & 6 & 2 & $12(3,4 \%)$ \\
\hline VŠHV & 1445 & 874 & 319 & 72 & 162 & 18 & $\begin{array}{c}252 \\
(17,4 \%)\end{array}$ \\
\hline VŠPLI & 737 & 552 & 82 & 51 & 11 & 41 & $103(14 \%)$ \\
\hline $\begin{array}{l}\text { Odbor chemicko- } \\
\text { technologického } \\
\text { inžinierstva SVŠT }\end{array}$ & 579 & 361 & 110 & 71 & 21 & 16 & $\begin{array}{c}108 \\
(18,6 \%)\end{array}$ \\
\hline $\begin{array}{l}\text { Odbor strojného } \\
\text { a elektrotechnického } \\
\text { inžinierstva SVŠT }\end{array}$ & 1101 & 679 & 226 & 155 & 37 & 4 & $\begin{array}{c}196 \\
(17,8 \%)\end{array}$ \\
\hline $\begin{array}{l}\text { Odbor inžinierskeho } \\
\text { stavitel'stva SVŠT }\end{array}$ & 637 & 406 & 150 & 37 & 38 & 6 & $81(12,7 \%)$ \\
\hline $\begin{array}{l}\text { Odbor špeciálnych } \\
\text { náuk SVŠT }\end{array}$ & 230 & 200 & 18 & 8 & 2 & 2 & $12(5 \%)$ \\
\hline SPOLU & 9970 & 6960 & 1805 & 554 & 467 & 184 & $\begin{array}{c}1205 \\
(12 \%)\end{array}$ \\
\hline
\end{tabular}

* Absolútny počet vylúčených je súhrnom čísel v stípcoch E, F a G, relatívny počet je percentuálnym podielom z číselných hodnôt v stípci B.

91 Tamže, Správa Vysokoškolského výboru KSS na zasadnutie sekretariátu ÚV KSS dňa 28.3.1949, príloha 1 . 
Ako vyplýva z predchádzajúcej tabulky 6, priemerný počet poslucháčov vylúčených zo štúdia po fáze pohovorov predstavoval približne dvanást percent. Pri detailnejšom pohlade sú však zretel'né značné rozdiely medzi jednotlivými fakultami a školami. Tie sú paradoxne v zretelnom rozpore so zaužívanou predstavou o ideologicky exponovaných fakultách (právnickej, filozofickej a pedagogickej), ktoré by mali byt podrobené prísnejšiemu politickému preverovaniu, a naopak o fakultách a školách ideologicky menej exponovaných (ekonomických a technických), ktoré bolo možné absolvovat aj s horším „kádrovým profilom“.

Na vysokom počte študentov a študentiek vylúčených z technických fakúlt sa podpísal aj pomerne vysoký počet neodovzdaných previerkových dotazníkov, ktorý mohol mat rôzne príčiny (pozri vyššie), k čomu sa pravdepodobne pridali osobné animozity a hypertrofovaná aktivita niektorých členov preverovacích komisií na týchto fakultách. Toto vysvetlenie sa javí ako pravdepodobné, ked’že sa doposial neobjavili spolahlivé dôkazy potvrdzujúce, že by študentstvo na fakultách postihnutých prísnejším vylučovaním poslucháčov malo odlišnú sociálnu štruktúru oproti ostatným školám alebo že by na ideologickej čistote týchto škôl osobitne záležalo predstavitelom komunistického režimu. Podobne tomu bolo zrejme v prípade Slovenskej vysokej školy obchodnej (Vysokej školy hospodárskych vied), ktorá tiež patrila $\mathrm{k}$ školám s najvyšším percentom vylúčených študentov a študentiek.

Naopak, nízke percento študujúcich vylúčených z Filozofickej a Pedagogickej fakulty Slovenskej univerzity a priemerné percento vylúčených študentov práva bolo pravdepodobne dôsledkom akútneho nedostatku absolventov týchto odborov v praxi, ${ }^{92}$ ktorý neumožňoval takú okamžitú a masívnu čistku spomedzi poslucháčov a ktorý aj fakultných funkcionárov nútil ku kompromisom medzi dvoma základnými princípmi charakterizujúcimi „lojálneho intelektuála“ - straníckostou a odbornostou. K týmto faktorom prispievala aj súdržnosť akademickej obce na týchto fakultách - tak študujúcich, ako aj pedagogického zboru - rovnako ako aj vel'mi nízke personálne zapojenie oboch kategórií do masových organizácií (komunistickej strany, Revolučného odborového hnutia, ČSM).${ }^{93} \mathrm{~K}$ zavŕšeniu „očisty“ týchto fakúlt tak došlo až v nasledujúcom roku počas takzvaného ideologického boja, ktorého obetou sa stal napríklad aj dekan Právnickej fakulty Slovenskej univerzity Karol Rebro a mnohí d’alší vyučujúci, ako aj študujúci. ${ }^{94}$

Táto druhá čistka mala masívny priebeh aj na Lekárskej fakulte Slovenskej univerzity, ktorý možno vysvetlit činnostou pomerne malej, ale vel'mi agilnej skupiny študentov a študentiek (a neskorších ašpirantov/ašpirantiek a asistentov/asistentiek), ktorí boli zároveň vysokopostavenými funkcionármi Československého zväzu mládeže. Tí podla pamätníkov na fakulte realizovali skutočnú „študentokraciu“,

92 SNA, f. ÚV KSS - tajomníci (Štefan Baštovanský), šk. 2191, Zpráva o Právnické fakultě Slovenské univerzity v Bratislavě, 1.3.1950.

93 Tamže. Podla informácie z 1. marca 1950 (t.j. viac než rok po „demokratizačnej“ čistke) bolo na právnickej fakulte členmi základnej organizácie KSS len dvadsat študentov (!) a členmi ČSM asi polovica, ale mnohí z nich len formálne kvôli výhodám.

94 Pozri GLOSSOVÁ, M.: Previerky a vylučovanie študentov slovenských vysokých škôl v rokoch 1948-1960 ako prostriedok výchovy lojálnych elít (pozri pozn. 41). 
ktorej pôsobenie malo konkrétne personálne dôsledky nielen pre kolegov a kolegyne $\mathrm{z}$ radov študentstva, ale aj pre vyučujúcich. ${ }^{95}$ Ich vel'ký vplyv podporovalo aj to, že lekárska fakulta bola suverénne najpočetnejšia ${ }^{96}$ a zároveň velmi homogénna na rozdiel od iných fakúlt, kde boli poslucháči v dôsledku štúdia množstva rozličných študijných programov rozdelení na menšie skupiny. Špecifickej radikalite čistiek na bratislavskej lekárskej fakulte po februári 1948 zodpovedá aj primát medikov pri ostrakizácii židovských študentov už v tridsiatych rokoch ${ }^{97}$ a pri šikanovaní českých vyučujúcich. Išlo tam zrejme o kontinuálny jav. Naopak, Filozofická fakulta Slovenskej univerzity mala už z obdobia Slovenského štátu tradíciu aktívneho vzdorovania politickej moci, ktorú sa tak rýchlo nepodarilo prelomit ani predstavitelom komunistického režimu, aj kvôli úzkym personálnym prepojeniam medzi vedením fakulty a povereníctva školstva.

\section{Odvolania}

Voči rozhodnutiu preverovacej komisie sa študenti a študentky podla pôvodných pokynov povereníctva školstva nemohli odvolat', avšak povereníctvo si vyhradilo právo schval'ovat jednotlivé vylúčenia, čo mu de facto zaručovalo pozíciu najvyššej inštancie. V apríli 1949 po zverejnení zoznamov vylúčených poslucháčov povereníctvo túto možnost využilo na zásah do výsledkov preverovania, ked’ predsa len zaviedlo možnosṫ odvolacieho konania, v ktorom sa malo rozhodovat "od prípadu k prípadu“. ${ }^{98}$ Argumentovalo, že zo škôl bolo vylúčených aj mnoho poslucháčov, ktorí v štúdiu nepostupovali zo zdravotných alebo sociálnych dôvodov a ktorým bolo podla povereníctva potrebné pomôct' sociálnou podporou, respektíve prostredníctvom Vysokoškolského zdravotného ústavu. Taktiež boli zo štúdia vylúčení aj poslucháči, ktorým pozostávalo len niekol'ko mesiacov do jeho ukončenia.

Zdá sa, že povereník Ladislav Novomeský voči týmto vysokoškolákom razil vlastnú, miernejšiu cestu. Rozhodol, že sa má voči nim postupovat’ „blahovolne“ a „umožnit - ak je to možné, aj bez odvolania - zloženie skúšok. Ak by ich [študent] na termín nezložil, samozrejme vstupuje v platnosț rozhodnutie preverovacej komisie o dočasnom, resp. úplnom vylúčení zo štúdia." ${ }^{\text {"99 }}$ Zároveň podnikol kroky

95 MEŠKO, Zoltán G.: Zamlčané sprisahanie: Politické čistky na lekárskej fakulte po druhej svetovej vojne. Bratislava, Slovak Academic Press 1999.

96 V školskom roku 1948/1949 mala Lekárska fakulta Slovenskej univerzity 2161 študentov a študentiek, d’alšia v poradí Právnická fakulta SU ich mala 1531. Tri fakulty - Filozofická fakulta SU a dve fakulty Slovenskej technickej univerzity - mali pätsto až tisíc poslucháčov, ostatné dokonca menej než pätsto.

97 SZABÓ, Miloslav: „Židé jsou neštěstím Slovenska“: Čechoslovakizmus a antisemitizmus na konci 19. a v prvej polovici 20. storočia. In: HUDEK, Adam - KOPEČEK, Michal - MERVART, Jan (ed.): Čechoslovakizmus. Praha, Nakladatelství Lidové noviny 2019, s. 139 n.

98 SNA, f. Povereníctvo školstva-povereníci - Laco Novomeský, šk. 13, Preverovacie pokračovanie a odvolacia komisia, list povereníka školstva Ladislava Novomeského kabinetu povereníctva a 5. odboru zo 14.4.1949.

99 Tamže. 
na medializáciu svojho plánu, ked' nariadil poskytnút potrebné materiály redaktorovi denníka Pravda a požiadat ho, aby „venoval v svojom článku o celej veci pozornost menovite po stránke študijnej, pričom, samozrejme, nech uvedie aj prípady, kde rozhodovali momenty politické, avšak konkrétne aké politické momenty to boli, ktoré preverovacie komisie $\mathrm{k}$ negatívnemu rozhodnutiu prinútilii“. 100

Zástupcovia Vysokoškolského výboru KSS s takýmto postupom nesúhlasili, pričom argumentovali, že spochybnením rozhodnutí o vylúčení niektorých študujúcich „by utrpela ich prestíž. Nech pán povereník vraj vymenuje odvolaciu komisiu a nech táto na veci zmení..." ${ }^{101}$ Novomeský sa preto rozhodol nečakat na návrh predstavitel'ov vysokoškolského výboru, ktorí „zbytočne zdržujú už tretí deň“, a vymenovat takú odvolaciu komisiu, v ktorej síce študenti a študentky budú mat’ svojich zástupcov, ale ktorej rozhodnutia nebudú závislé od ich hlasov. Za členov komisie

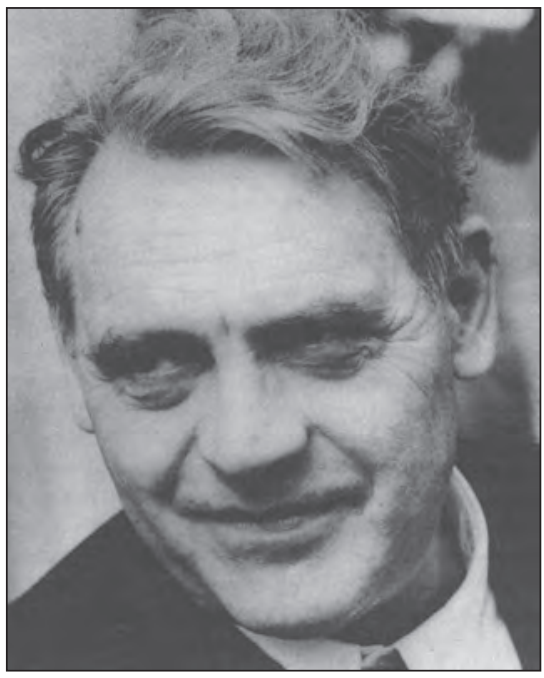

Spisovatel', publicista a komunistický politik Ladislav Novomeský (1904-1976) sa ako povereník školstva, vied a umení zaslúžil o zmiernenie výsledkov prvej čistky na slovenských vysokých školách (foto www.cojeco.cz) boli menovaní pracovníci povereníctva R. Martiš, P. Pazúr, I. Rosa a E. Markovič, ktorí mali spolu s predsedom Ernestom Ottom pät hlasov. Za vysokoškolákov boli do komisie menovaní dvaja študenti (Čech a Matula), no ked’že komisia mala „zasadat v takom zložení, aby boli prítomní vždy piati členovia“, ${ }^{102}$ mala ich účast v komisii len kozmetickú funkciu.

Pôsobenie odvolacej komisie a jej závery medzi realizátormi previerky vyvolali vel'kú nevôlu. Komisia totiž podla správy o konečných výsledkoch „demokratizácie“ až takmer polovicu odvolaní vybavila kladne, čím „vznikol chaos“ a „celú demokratizačnú akciu fakticky odsabotovala“. ${ }^{103}$ Povereníctvo školstva okrem toho podla

100 Tamže.

101 Tamže, list pracovníka povereníctva dr. Reháka s návrhom na kreovanie odvolacej komisie povereníkovi Novomeskému z 5.5.1949.

102 Tamže, Preverovacie pokračovanie a odvolacia komisia, Menovanie odvolacej komisie na PŠVU [povereníctvu školstva, vedy a umení], 6.5.1949 (vyznačené podčiarknutím v origináli).

103 Tamže, f. ÚV KSS - sekretariát, šk. 7, Konečné výsledky demokratizačnej akcie na slovenských vysokých školách a návrh na niektoré opatrenia, 20.4.1950. 
tejto správy, vypracovanej sekretariátom Ústredného výboru KSS v apríli 1950, prijímalo odvolania aj po ukončení oficiálnej činnosti odvolacej komisie. ${ }^{104}$

Tento výklad sekretariátu ÚV KSS, ktorý ústil v požiadavku „znovu preskúmat prípady tých poslucháčov, ktorí sa odvolali proti rozhodnutiu hlavných disciplinárnych ${ }^{105}$ komisií a ktoré odvolacia disciplinárna komisia pri PŠVU vybavila kladne", ${ }^{106}$ však slúžil najmä na zdôvodnenie novej čistky o rok neskôr, pripravovanej v marci a apríli 1950 a realizovanej v júni, septembri a októbri toho roku. Zároveň sa stal súčastou obvinenia hlavných činitelov zodpovedných za odvolacie konanie - predsedu odvolacej komisie Ernesta Ottu a samotného povereníka Laca Novomeského - z nedostatočne dogmatického prístupu. Počas tejto čistky, ktorej oficiálnym zdôvodnením bol boj proti „slovenskému buržoáznemu nacionalizmu“ a „ideologický boj“ na vysokých školách, bolo v júni 1950 vylúčených 105 študentov a študentiek a na jeseň d’alších 465 študujúcich; ${ }^{107}$ väčšina z nich napriek tomu, že „demokratizáciou" na minulý rok prešli úspešne alebo s podmienkou.

V skutočnosti však zásah odvolacej komisie v roku 1949 - najmä v prípade velkých fakúlt - nebol až taký dramatický a počet vylúčených študentov a študentiek v priemere znížil len o približne dve percentá. ${ }^{108}$

Tab. 7: Výsledky „demokratizácie“ na slovenských vysokých školách pred a po odvolacom konaní1 ${ }^{109}$

\begin{tabular}{|c|c|c|c|c|c|c|c|c|}
\hline $\mathrm{A}$ & B & $\mathrm{C}$ & $\mathrm{D}$ & $\mathrm{E}$ & $\mathrm{F}$ & G & $\mathrm{H}$ & I \\
\hline & \multirow[b]{2}{*}{ 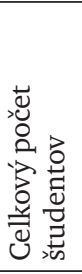 } & \multirow[b]{2}{*}{ 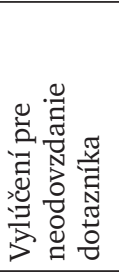 } & \multicolumn{2}{|c|}{$\begin{array}{l}\text { Vylúčení dočasne } \\
\text { (na 2-3 semestre) }\end{array}$} & \multicolumn{2}{|c|}{$\begin{array}{l}\text { Vylúčení } \\
\text { natrvalo }\end{array}$} & \multicolumn{2}{|c|}{ Vylúčení spolu* } \\
\hline Škola & & & 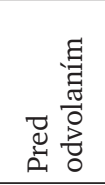 & $\begin{array}{l}\text { ]ี } \\
\frac{1}{0} \\
0 \\
0 \\
0 \\
0 \\
0\end{array}$ & 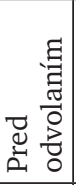 & 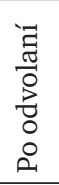 & 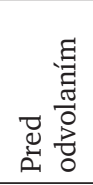 & 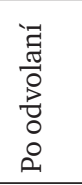 \\
\hline Právnická f. SU & 1392 & 67 & 26 & 13 & 79 & 52 & 172 & 132 \\
\hline Filozofická f. SU & 886 & 0 & 6 & 5 & 3 & 0 & 9 & 5 \\
\hline Pedagogická f. SU & 182 & 0 & 4 & 3 & 0 & 0 & 4 & 3 \\
\hline Prírodovedecká f. SU & 426 & $16 / 0 * *$ & 1 & 0 & 1 & 0 & 18 & 0 \\
\hline
\end{tabular}

104 Výsledky zachytené v nasledujúcej tabul'ke 7 tak nemusia byṫ definitívne, ked’že už nezobrazujú tento možný vývoj po ukončení oficiálnej činnosti odvolacej komisie.

105 V skutočnosti niesli názov „hlavné preverovacie komisie“.

106 Tamže.

107 Tamže, šk. 22, Návrh na znovuprijímanie poslucháčov, vylúčených v demokratizácii, na vysoké školy, 13.7.1951.

108 Pozri tabulku 7, porovnanie stípcov D, F, H so stípcami E, G, I.

109 Tamže, f. ÚV KSS - tajomníci (Štefan Baštovanský), šk. 2, Správa Vysokoškolského výboru KSS na zasadnutie sekretariátu ÚV KSS dňa 28.3.1949. 


\begin{tabular}{|l|c|c|c|c|c|c|c|c|}
\hline Lekárska f. SU & 2004 & 73 & 153 & 124 & 12 & 11 & 238 & 208 \\
\hline Farmaceutická f. SU & 351 & 4 & 6 & 1 & 2 & 1 & 12 & 6 \\
\hline VŠHV & 1445 & 72 & 162 & 142 & 18 & 14 & 252 & 228 \\
\hline VŠPLI & 737 & 51 & 11 & 8 & 41 & 29 & 103 & 88 \\
\hline $\begin{array}{l}\text { Odbor chemicko- } \\
\text { technologického } \\
\text { inžinierstva SVŠT }\end{array}$ & 579 & $71 / 60$ & 21 & 20 & 16 & 16 & 108 & 96 \\
\hline $\begin{array}{l}\text { Odbor strojného } \\
\text { a elektrotechnického } \\
\text { inžinierstva SVŠT }\end{array}$ & 1101 & 155 & 37 & 22 & 4 & 4 & 196 & 181 \\
\hline $\begin{array}{l}\text { Odbor inžinierskeho } \\
\text { stavitel'stva SVŠT }\end{array}$ & 637 & $37 / 28$ & 38 & 26 & 6 & 5 & 81 & 59 \\
\hline $\begin{array}{l}\text { Odbor špeciálnych } \\
\text { náuk SVŠT }\end{array}$ & 230 & 30 & 2 & 0 & 2 & 2 & 12 & 32 \\
\hline SPOLU & $\mathbf{9 9 7 0}$ & $\mathbf{5 7 6 / 5 4 0}$ & $\mathbf{4 6 7}$ & $\mathbf{3 6 4}$ & $\mathbf{1 8 4}$ & $\mathbf{1 3 4}$ & $\begin{array}{c}\mathbf{1 2 0 5} \\
\mathbf{( 1 2} \% \mathbf{)}\end{array}$ & $\begin{array}{c}\mathbf{1 0 3 8} \\
\mathbf{( 1 0 4 )}\end{array}$ \\
\hline
\end{tabular}

* Počty spolu vylúčených pred odvolacím konaním (stípec H) sú súčtom údajov v stĺpcoch C, D a F. Počty spolu vylúčených po odvolacom konaní (stlpec I) sú súčtom údajov v stĺpcoch C, E a G.

** Ide o údaje z dvoch tabuliek nasledujúcich po sebe s niekolkotýždňovým rozostupom, ktoré sa týkajú Prírodovedeckej fakulty SU a dvoch fakúlt SVŠT. Aj tieto čísla naznačujú dodatočné odovzdávanie dotazníkov „po termíne“. V konečnom výsledku vylúčených poslucháčov pred odvolacím konaním (stĺpec H) je započítané vyššie číslo, po odvolacom konaní (stípec I) nižšie číslo.

Ako sa dá usudzovat z d’alšieho vývoja udalostí, je pravdepodobné, že do určitej miery autonómny postoj ${ }^{110}$ povereníka Novomeského a predsedu odvolacej komisie Ernesta Ottu, ktorý bol osobným tajomníkom Novomeského, sa stal jednou z príčin, ktoré napokon viedli ku koncu ich politickej kariéry v súvislosti s kampaňou proti „slovenskému buržoáznemu nacionalizmu“. Ernest Otto bol zatknutý dokonca ešte počas trvania činnosti odvolacej komisie v roku 1949 ako „titoistický agent“ a odsúdený na trest smrti, ktorý mu bol neskôr zmenený na doživotie. Z väzenia bol prepustený na amnestiu v roku 1960, o dva roky neskôr však za nevyjasnených okolností pravdepodobne spáchal samovraždu. Ladislava Novomeského ako povereníka školstva po deviatom zjazde KSS v máji 1950 nahradil Ernest Sýkora, on sám

110 O vol’nejšej atmosfére na povereníctve školstva svedčí aj príbeh pamätníčky Angely Bajnokovej (rodenej Jankevičovej), dcéry gréckokatolíckeho kňaza, ktorá koncom 40. rokov pracovala na povereníctve školstva ako úradníčka. Jej snúbenca Jozefa Bajnoka, ktorý študoval na Chemicko-technologickej fakulte STU, vylúčili (pravdepodobne) počas čistky na jeseň 1950, „pretože chodí s farárovou dcérou“. Samotná „farárova dcéra“ Angela však na povereníctve školstva problémy nemala. (BAJNOKOVÁ, Angela (*1928): Snažit sa žit a robit dobrotu, nikomu zle. Rozhovor natočil a spracoval Ján Golian. In: Pamět národa [online]. (C) Príbehy 20. storočia [cit. 2019-03-27]. Dostupné z: https://www.pametnaroda.cz/ sk/bajnokova-angela-20171116-0.) 
bol nasledujúci rok zatknutý a v roku 1954 odsúdený v procese so „slovenskými buržoáznymi nacionalistami“" na desatročný trest. V roku 1956 bol podmienečne prepustený na slobodu a po rehabilitácii v roku 1963 mohol znovu vstúpit do komunistickej strany a vrátił sa do verejného a politického života.

\section{„Ideologická prevýchova“ vo výrobe a opätovné prijímanie na štúdium}

Študenti a študentky slovenských vysokých škôl, pre ktorých sa takzvaná demokratizácia v roku 1949 skončila verdiktom trvalého alebo dočasného vylúčenia, boli určení na prácu vo výrobe. Po ukončení previerky sa mali prihlásit na Vysokoškolskom výbore ČSM a ich zarad’ovanie do výroby malo uskutočňovat povereníctvo práce a sociálnej starostlivosti. Hoci umiestňovanie do výroby sa malo diat na báze dobrovolnosti a malo sa pri ňom vychádzat zo zásady, „aby každý dla možnosti pracoval i v takom odbore, na aký sa pripravoval počas štúdia“" ${ }^{111}$ v skutočnosti bolo pracovné zaradenie študentov tiež formou trestu. Dobrovolný výber pracovného miesta bol automaticky znemožnený vylúčeným poslucháčom „ideologických“ fakúlt (teda filozofickej, právnickej a Vysokej školy hospodárskych vied) a tiež študujúcim vylúčeným z politických dôvodov (povereníctvo práce a sociálnej starostlivosti ich malo preškolit a zaradit do výroby; v prípade, že už mali zamestnanie, mali byt prepustení). ${ }^{112}$ Dobrovol'ný výber zamestnania sa tak týkal len vysokoškolákov prepustených zo študijných dôvodov - teda tých, ktorých potrestanie bolo hlavným deklarovaným cielom „demokratizácie“.

Realita však celkom nezodpovedala zamýšlanému cielu „ideologickej prevýchovy“ vylúčených študentov a študentiek, ktorí si vo výrobe mali „osvedčit svoj nový, kladný vztah k ludovej demokracii a k robotníckej triede“. ${ }^{113}$ Ked’že v roku 1949 nebol pojem „zaradenia do výroby“ špecificky určený ako manuálna práca, podla správy kultúrno-propagačného oddelenia sekretariátu ÚV KSS z neskoršieho obdobia naozaj „väčšina študentov určených do výroby nenastúpila do manuálnej práce, časť z nich si individuálne našla zamestnanie v kancelárskej a technickej službe, mnohí z tých, čo nastúpili do manuálnej práce, boli podnikom preradení do administratívnej a technickej práce“. ${ }^{114}$ Určitá čast dočasne vylúčených študentov bola tiež povolaná na vojenskú prezenčnú službu, pričom niektorí z nich museli absolvovat vojenskú službu „bez zbrane“, t.j. v pomocných technických práporoch.

Po uplynutí určenej doby (dvoch alebo troch semestrov) mohli dočasne vylúčení študenti a študentky požiadat’ o opätovné prijatie na vysokú školu. Podmienkou pre prijatie mala byt aspoň ročná manuálna práca, pri ktorej dotyčný získal titul

111 SNA, f. ÚV KSS - sekretariát, šk. 7, Konečné výsledky demokratizačnej akcie na slovenských vysokých školách a návrh na niektoré opatrenia, 20.4.1950.

112 Tamže, šk. 2, Správa VV KSS o priebehu demokratizácie slovenských vysokých škôl, 2.3.1949.

113 Tamže, šk. 22, Návrh na znovuprijímanie poslucháčov, vylúčených v demokratizácii, na vysoké školy, 13.7.1951.

114 Tamže. 
„úderníka“ a zároveň vedel preukázat aktívnu činnost v masových organizáciách. „Nový vztah k ludovej demokracii a k robotníckej triede“115 sa mal individuálne skúmat na základe posudkov z pracoviska i z rodiska uchádzača o opätovné prijatie na štúdium. Ako hlavné kritérium sa zdôrazňoval správny triedny pôvod.

Formálny postup žiadosti o opätovné prijatie na štúdium spočíval v jej podaní tajomníkovi príslušnej fakulty a v následnom prerokovaní komisiou pozostávajúcou z dekana, tajomníka fakulty, predsedu fakultnej základnej organizácie KSS a podpredsedu Vysokoškolského výboru ČSM. Úloha Vysokoškolského výboru KSS, ktorý hral klúčovú rolu pri preverovaní študentov a študentiek, sa posunula do personálnej oblasti: pre komisiu mal prostredníctvom okresných výborov KSS zabezpečit kádrový posudok dotyčného z jeho bydliska.

Zamietnutie žiadosti, ktorá nespíňala určené podmienky, bolo v kompetencii fakultnej komisie. O žiadostiach, ktoré formálne požiadavky splnili, následne rozhodovala ústredná komisia zriadená povereníctvom školstva, ktorej členmi boli predseda kádrového odboru, prednosta školského odboru, rektor príslušnej školy, zástupca okresného výboru KSS a zástupca okresného výboru ČSM. Údaje o skutočnom počte znovu prijatých študentov a študentiek však už materiály sekretariátu Ústredného výboru KSS neobsahujú. Známe sú len čiastkové údaje z Archívu Slovenskej technickej univerzity, podla ktorých boli opätovne prijatí na štúdium len jednotlivci. Treba tiež poznamenat, že pokyn Ústredného výboru KSS umožnit vylúčeným študentom opätovné prijatie na štúdium prišiel v čase prebiehajúceho „ideologického boja“ proti takzvanému buržoáznemu nacionalizmu na vysokých školách, ktorý sprevádzala d’alšia čistka. Možnoste „prevychovaných“ vysokoškolákov, ktorí boli vylúčeni pri predošlej čistke, požiadat’ o opätovné prijatie na štúdium mala propagandisticky slúžit na zmiernenie prípadného napätia medzi študentstvom pri d’alšej vlne vylučovania. ${ }^{116}$

\section{Záverom}

Študijno-politická previerka, ktorá sa pod názvom „demokratizácia“ uskutočnila na slovenských vysokých školách v januári a februári roku 1949, bola čo do celkového počtu vylúčených poslucháčov najmasívnejšou vlnou „očisty“ vysokých škôl na Slovensku v prvých rokoch fungovania komunistického režimu. Zo škôl muselo natrvalo alebo dočasne odíst 1038 študentov a študentiek, čo boli 10,4 percentá všetkých vysokoškolákov. Hoci bežne používaný názov „demokratizácia“ odkazoval na snahu o zmenu sociálnej štruktúry študentstva, čím nadväzoval na Košický vládny program, v skutočnosti išlo o študijnú a najmä politickú previerku. Triedny pôvod a zámožnost̉ rodičov predstavovali jedno z kritérií v rámci politického preverovania.

115 Tamže.

116 Tam̌̌e, šk. 10, Správa o prieskume vysokoškolákov, 7.9.1950. 
„Demokratizácia“ na Slovensku sa vo viacerých aspektoch líšila od analogickej „študijnej previerky“ na českých vysokých školách. ${ }^{117}$ Termínovo bola posunutá o jeden až dva mesiace neskôr, jej hlavným realizátorom bol Vysokoškolský výbor KSS (na rozdiel od Ústredného akčného výboru Národného frontu na vysokých školách v Čechách a na Morave) a na previerkové pohovory neboli pozvaní všetci študenti, ale len tí, ktorí podla výsledkov vopred vypíňaných dotazníkov a „kádrovania“ v mieste trvalého bydliska spadali do „problematických“ kategórií, či už zo študijného, alebo politického hladiska.

Táto „očista“ slovenských vysokých škôl prekvapujúco nebola až taká brutálna, ako predpokladali členovia Vysokoškolského výboru KSS, teda najangažovanejší poslucháči a hlavní organizátori previerky, ani ako by sa dalo usudzovat na základe výsledkov previerky na českých a moravských vysokých školách, na ktorých nebola preverená až zhruba štvrtina študentov a študentiek. Napriek pôvodným odhadom Vysokoškolského výboru KSS, v ktorých sa počty kandidátov na vylúčenie pohybovali v desiatkach percent, bola napokon zo štúdia vylúčená „len“ desatina poslucháčov, z toho približne tretina dočasne na dva až tri semestre a po uplynutí stanovenej lehoty mohla požiadat’ o opätovné prijatie na štúdium.

Najvyššie percento vylúčených študentov a študentiek pripadalo na Vysokú školu hospodárskych vied (skôr Slovenskú vysokú školu obchodnú) a na niektoré fakulty Slovenskej vysokej školy technickej. V prípade Fakulty strojného a elektrotechnického inžinierstva SVŠT sa na vysokom počte vylúčených pravdepodobne podpísalo aj to, že mnohí poslucháči vôbec nevyplnili, respektíve neodovzdali previerkový dotazník, čím boli zo štúdia vylúčení automaticky. Na Slovenskej univerzite (neskôr Univerzite Komenského) bolo pomerne vela poslucháčov vylúčených zo štúdia práva a medicíny; naopak prekvapujúco málo boli čistkami postihnuté fakulty filozofická, pedagogická a prírodovedecká. Tieto zistenia v súhrne nabúravajú predpoklad o politickej exponovanosti „ideologických“ fakúlt (filozofickej, pedagogickej, právnickej) a relatívne väčšej „slobode“ na školách technického zamerania, ktorá v tomto počiatočnom období komunistického režimu ešte pravdepodobne neplatila.

Možné vysvetlenie relatívnej miernosti „demokratizačnej akcie“ na Slovensku spočiva $v$ súhre troch faktorov:

Prvým z nich bola celkovo poddimenzovaná personálna situácia nielen na vysokých školách, ale aj v štátnej správe a v hospodárskom sektore na Slovensku. Nedostatok odborníkov neumožňoval také radikálne vylučovanie pedagógov ani poslucháčov (budúcich absolventov a absolventiek), lebo ich jednoducho nebolo kým nahradit. Aj politickú elitu na jednotlivých fakultách tak nútil ku kompromisom medzi ideálnym kádrovým profilom jednotlivých preverovaných osôb a ich odbornostou. Toto vákuum zároveň vytváralo priestor pre osobné intervencie, a to tak v prospech preverovaných vysokoškolákov (ked' mohli čistke uniknút aj študujúci s nevyhovujúcim kádrovým profilom), ako aj v ich neprospech (zámienku na vylúčenie $\mathrm{v}$ podobe údajne problematického príbuzného či deliktu v minulosti rodiny bolo možné nájsť v profile takmer každého študujúceho). Triedna a politická

117 Pozri JAREŠ, J.: „Indiferentní - možnost převýchovy!“ (pozri pozn. 11). 
„očista“ vysokých škôl sa tak na Slovensku nemohla uskutočnit naraz, ako to bolo na českých vysokých školách, ale v dvoch etapách, pričom až druhá z nich, ktorá sa konala v júni a na jeseň 1950 v atmosfére vybičovanej kampane proti „slovenskému buržoáznemu nacionalizmu“, bola skutočným zavŕšením politickej „očisty“ vysokých škôl.

Druhou príčinou bola pomerne liberálna atmosféra na niektorých fakultách. Komunisti boli v profesorskom zbore aj medzi študujúcimi v menšine, slabé a formálne bolo aj ich zapojenie do masových organizácií (ROH, ČSM). Až postupne si režim z nových vedeckých pracovníkov, regrutovaných prostredníctvom Československého zväzu mládeže spomedzi angažovaných študentov a študentiek, budoval vrstvu lojálnych odborníkov, ktorými pri d’alších čistkách mohol nahrádzat „nevyhovujúcich" učitelov a učitelky. Táto ideologická autonómia akademickej obce niektorých fakúlt v závere štyridsiatych rokov - spolu s určitou tradíciou vzdorovania totalitnej moci ešte z obdobia Slovenského štátu a s úzkou personálnou zomknutostou málopočetnej intelektuálnej elity - tiež pravdepodobne prispela k tomu, že previerka namierená voči „nevyhovujúcim“ študentom a študentkám sa realizovala len v pomerne obmedzenej miere.

Po tretie, na pomerne „slabý“ výsledok „demokratizácie“ na Slovensku mal vplyv aj postoj predstavitelov povereníctva školstva, vied a umení (predsedu odvolacej komisie Ernesta Ottu a povereníka Ladislava Novomeského), ktorí nepatrili k najdogmatickejším komunistom a vo vztahu k preverovaným poslucháčom razili miernejší prístup. Prostredníctvom odvolacej komisie pri povereníctve školstva nemalej časti vylúčených študentov a študentiek umožnili návrat na vysokú školu, čím sa dostali do konfliktu s Vysokoškolským výborom KSS. Je možné, že tento ich postoj bol jednou z príčin vedúcich $\mathrm{k}$ obvineniu zo „slovenského buržoázneho nacionalizmu“, ktoré v nasledujúcom roku malo za následok ich odvolanie z funkcií a následnú perzekúciu.

Prečo tolko študentov a študentiek Fakulty strojného a elektrotechnického inžinierstva SVŠT vôbec neodovzdalo dotazníky a prečo bolo tolko poslucháčov vylúčených z technických fakúlt a z Vysokej školy hospodárskych vied, sa nepodarilo spolahlivo zistit. Môžeme preto len usudzovat, že na týchto fakultách vyššie spomenuté faktory pretrvávajúcej rezistencie voči politickým tlakom a personálnej zomknutosti až tak neplatili a že relatívna prísnost̉ preverovacích komisií bola dôsledkom príležitosti, osobnej angažovanosti a hypertrofovanej aktivity ich členov.

Nespokojnost komunistických špičiek s realizáciou „očisty“ v roku 1949 a s personálnym stavom na slovenských vysokých školách viedla $\mathrm{k}$ d’alšej vlne preverovania a vylučovania, tentoraz celkom nemilosrdnej, ktorej podnetom sa stalo vypuknutie kampane proti takzvanému slovenskému buržoáznemu nacionalizmu na jar 1950. Atmosféra nepredvídatel’nosti, strachu a obáv o vlastný osud, zmenené vedenie povereníctva školstva a skonsolidované tvrdé jadro komunistických študentov a študentiek na vysokých školách spôsobili, že v priebehu piatich mesiacov od júna do októbra 1950 došlo k skutočnému „zúčtovaniu“ s prívržencami a sympatizantmi bývalého režimu, a to tak medzi študentstvom, ako aj medzi pedagogickým zborom. Počas tejto čistky bolo zo štúdia vylúčených d’alších 570 poslucháčov. To je 
síce takmer dvakrát menej než pri predošlej akcii v roku 1949, pokial’ však tento úbytok vyjadríme relatívne (11,12 percent), bola táto čistka ešte drastickejšia ako takzvaná demokratizácia. Tento rozpor je len zdanlivý, pretože nová čistka v rámci takzvaného ideologického boja sa odohrávala počas prázdnin medzi dvoma akademickými rokmi, čo znamená, že zasiahla o jeden populačný ročník menej. Uchádzači o štúdium prvého ročníka v nasledujúcom akademickom roku 1950/1951 boli tiež podrobení sprísnenému prijímaciemu konaniu, pre ktoré platili rovnaké kritériá ako pre čistku už prijatých vysokoškolákov. Počet takto odmietnutých uchádzačov o štúdium však nie je známy, a nedá sa tak započítat do celkového počtu „vylúčených“. Táto druhá čistka na slovenských vysokých školách nemá svoju českú paralelu a okrem niekol'kých okrajových zmienok sa jej doposial' takmer vôbec nevenovala ani slovenská historiografia. Zistenia vyplývajúce z analýzy relevantných archívnych prameňov tak ešte len čakajú na svoje publikovanie. 